\title{
Induction of Interleukin-1 Associated with Compensatory Dopaminergic Sprouting in the Denervated Striatum of Young Mice: Model of Aging and Neurodegenerative Disease
}

\author{
Angela Ho and Mariann Blum \\ Fishberg Research Center for Neurobiology, Mount Sinai School of Medicine, New York, New York 10029
}

Young mice challenged with the neurotoxin 1-methyl-4-phenyl1,2,3,6-tetrahydropyridine (MPTP), which selectively destroys the substantia nigra dopaminergic neurons in the midbrain, exhibit spontaneous recovery of dopaminergic nerve terminals. However, such recovery becomes attenuated with age. Here we report that newly sprouted fibers originate from spared dopaminergic neurons in the ventral tegmental area. We found that interleukin-1 (IL-1), an immune response-generated cytokine that can enhance dopaminergic sprouting when exogenously applied, increased dramatically in the denervated striatum of young mice (2 months) compared with middle-aged mice (8 months) after MPTP treatment. Young mice displayed a maximal $500 \%$ induction of IL-1 $\alpha$ synthesis that remained elevated for several weeks in the dorsal and ventral striatum, whereas middle-aged mice exhibited a modest $135 \%$ induction exclusively in the dorsal striatum for a week. IL-1 $\alpha$ immunoreactivity was localized in GFAP-immunoreactive hypertrophied astro- cytes and neurons within the denervated striatum of young mice. However, no induction of IL-1 $\alpha$ mRNA was seen in the midbrain in either age group despite glial activation. Because we have reported that IL-1 can regulate astroglia-derived dopaminergic neurotrophic factors, it was surprising that no changes were observed in acidic and basic fibroblast growth factor or glial cell line-derived neurotrophic factor mRNA levels associated with MPTP-induced plasticity of dopaminergic neurons in the striatum of young mice. Interestingly, we found that dopaminergic neurons express IL-1 receptors, thus suggesting that IL-1 $\alpha$ could directly act as a target-derived dopaminergic neurotrophic factor to initiate or enhance the sprouting of dopaminergic axonal terminals. These findings strongly suggest that IL- $1 \alpha$ could play an important role in MPTP-induced plasticity of dopaminergic neurons.

Key words: IL-1; compensatory sprouting; dopaminergic neurons; growth factors; MPTP; Parkinson's disease; aging
The mesostriatal dopaminergic system plays an important role in the control of voluntary movement. This system comprises midbrain dopaminergic cell groups and their projections to the entire striatal complex that consists of a dorsal and ventral component (Björklund and Lindvall, 1984). In the rodent, the dorsal striatum (caudate-putamen) is innervated mainly by dopaminergic neurons in the substantia nigra pars compacta $(\mathrm{SN})$, whereas the ventral striatum (nucleus accumbens and the olfactory tubercle) receives projections from cells in the ventral tegmental area (VTA) and the retrorubral area (Björklund and Lindvall, 1984). Selective degeneration of the mesostriatal pathway leads to motor impairments in Parkinson's disease (PD), which is characterized by the loss of dopaminergic neurons in the $\mathrm{SN}$ that leads to a preferential depletion in dopaminergic innervation of the dorsal striatum; however, cells in the VTA and the retrorubral area are much less affected (Agid et al., 1987; Hirsch et al., 1988; German et al., 1989; Hornykiewicz, 1993).

A neurotoxin, 1-methyl-4-phenyl-1,2,3,6-tetrahydropyridine (MPTP), that selectively destroys the SN dopaminergic cells has been used to produce an animal model of PD (Langston, 1985; Singer and Ramsay, 1990). In experimental animals, the neuro-

\footnotetext{
Received Feb. 10, 1998; revised May 22, 1998; accepted May 25, 1998.

This work was supported by National Institutes of Health Grant AG-08538. We are grateful to Brett M. Morrison for his help with the confocal images and Andrew Leonard for his help with the figures. We thank Esther García de Yébenes, Patrick R. Hof, Jeremy Kay, and Marie Zurich for their critical review of this manuscript. Correspondence should be addressed to Dr. Mariann Blum, Fishberg Research Center for Neurobiology, Mount Sinai School of Medicine, One Gustave L. Levy Place, Box 1065, New York, New York 10029

Copyright (C) 1998 Society for Neuroscience $\quad 0270-6474 / 98 / 185614-16 \$ 05.00 / 0$
}

degenerative effects of MPTP are age-dependent; that is, young mice show a substantial recovery of striatal dopamine, whereas aged mice do not (Ricaurte et al., 1986, 1987a,b; Date et al., 1990a). Thus, the dopaminergic cell system exhibits compensatory mechanisms in response to injury, and the degree of plasticity becomes reduced with age (Hornykiewicz, 1993). In this report, we sought to determine the origin of dopaminergic fibers responsible for the spontaneous axonal regrowth in the denervated striatum of young mice. More importantly, we examined the cellular and molecular events associated with the dopaminergic sprouting that occurs selectively in the denervated striatum of young but not middle-aged mice after MPTP treatment.

Glial cells play an integral role in the brain response to neuronal injury and plasticity (Eddleston and Mücke, 1993; Moore and Thanos, 1996). Injury to the brain elicits a sequence of morphological and biochemical events mediated by activated microglia that can release inflammatory cytokines such as interleukin-1 (IL-1) (Giulian et al., 1986, 1987, 1989, 1990). IL-1, in turn, can stimulate reactive astrocytes and enhance the synthesis of neurotrophic factors from astrocytes, thereby promoting axonal sprouting (Giulian and Lachman, 1985; Giulian et al., 1988; Spranger et al., 1990; Araujo and Cotman, 1992). It was shown that intrastriatal implantation of IL-1 can enhance compensatory sprouting from residual dopaminergic neurons in the VTA and can induce behavioral improvement in hemiparkinsonian rats (Wang et al., 1994). Recently, we have reported that basic fibroblast growth factor (bFGF) may be the putative dopaminergic neurotrophic factor that mediates IL-1 lesion-induced plasticity of dopaminergic neurons because intraventricular ad- 
ministration of IL-1 induces bFGF gene expression (Ho and Blum, 1997).

In the present study, we investigated the potential role of IL-1 and trophic factor activities in mediating the spontaneous dopaminergic sprouting in the denervated striatum of young but not middle-aged mice after MPTP treatment. We hypothesized that perhaps in the aging brain, the ability to induce growthpromoting molecules such as IL-1 and the subsequent induction of trophic factor synthesis declines with age. An understanding of the cascade of cytokine and trophic factor activities could provide insights into basic mechanisms of aging and their relationship to the process of dopaminergic cell death in PD.

\section{MATERIALS AND METHODS}

Drug administration. Male C57BL/6 mice (Harlan Sprague Dawley, Indianapolis, IN) of two different age groups were used: 8 weeks (young) and 8 months (middle-aged) of age. MPTP hydrochloride (Research Biochemicals, Natick, MA) was administered subcutaneously. Young mice received a single dose of MPTP at $55 \mathrm{mg} / \mathrm{kg}$, and middle-aged mice received a single dose at $40 \mathrm{mg} / \mathrm{kg}$. These doses were selected based on titration studies that produced comparable initial depletions of dopamine uptake in the striatum of young and older mice. Age-matched controls received saline. Animals were killed at 4, 8, 14, 21, and $30 \mathrm{~d}$ after the lesion along with their age-matched controls $(n=4-5 /$ group $)$. All animal experiments were conducted according to the Guidelines for the Care and Use of Experimental Animals, using protocols approved by the Institutional Animal Care and Use Committee at Mount Sinai School of Medicine (95-300NB).

$\left[{ }^{3} H\right]$ Dopamine uptake. Animals were decapitated, and the brains were quickly removed and placed into cold sterile saline. The dorsal and ventral striatum were dissected, and the anterior commissure was used as an anatomical landmark to distinguish between the dorsal and ventral striatum. Tissue above the anterior commissure was removed bilaterally and collected for the dorsal striatum, whereas tissue below the anterior commissure was collected for the ventral striatum. Tissues were homogenized in $500 \mu \mathrm{l}$ of ice-cold prelysis buffer ( $10 \mathrm{~mm}$ Tris, $\mathrm{pH}$ 7.5, and 0.32 M sucrose) using a Teflon pestle-glass mortar pair as described by Roffler-Tarlov et al. (1990). Homogenized tissue (100 $\mu$ l) was removed and centrifuged for $10 \mathrm{~min}$ at $1000 \times g$ at $4^{\circ} \mathrm{C}$ to remove nuclei. The supernatant containing the synaptosomes was collected, and aliquots were removed for the determination of protein concentration and dopamine uptake (total high-affinity and mazindol noninhibitable). Fifty microliters of supernatant were diluted in $450 \mu \mathrm{l}$ of Krebs-Ringer phosphate buffer $(0.1 \mathrm{M})$ with added EDTA $(1.3 \mathrm{~mm})$, glucose $(5.6 \mathrm{~mm})$, and ascorbic acid $(0.2 \mathrm{mg} / \mathrm{ml})$ and incubated at $37^{\circ} \mathrm{C}$ in the presence or absence of $10 \mu \mathrm{M}$ mazindol (Research Biochemicals), a high-affinity dopamine uptake inhibitor. $\left[{ }^{3} \mathrm{H}\right]$ Dopamine (specific activity, $20-40 \mathrm{Ci}$ / mmol; Amersham, Arlington Heights, IL) was added to a final concentration of $0.025 \mu \mathrm{M}$, and incubation was at $37^{\circ} \mathrm{C}$ for $6 \mathrm{~min}$. Synaptosomes were collected on presoaked nitrocellulose filters by filtration, and nonspecific radioactivity was washed with Krebs-Ringer phosphate buffer followed by filtration. The filters were then transferred into scintillation vials of Hionic-fluor and measured by liquid scintillation spectrometry. Specific high-affinity neuronal dopamine uptake was expressed as femtomoles of dopamine uptake per microgram of protein minus the femtomoles of mazindol uptake. Values are presented as the change in dopamine uptake (expressed as percent of control).

Immunocytochemistry. Animals were anesthetized with Rompun xylazine and Ketaset (1:1) and killed by intracardiac perfusion with $1 \%$ paraformaldehyde in $0.15 \mathrm{M}$ phosphate buffer, $\mathrm{pH} 7.2$ (PBS), followed by $4 \%$ paraformaldehyde. Brains were post-fixed for $5 \mathrm{hr}$ at $4^{\circ} \mathrm{C}$ and cryoprotected with $30 \%$ sucrose. Tissues were frozen with ornithine carbamyl transferase (Tissue Tek, Torrance, CA) embedding medium immersed in a dry-ice-chilled isopentane bath. Thirty micrometer coronal sections were cut using a cryostat and were processed for immunocytochemistry. Sections were incubated in blocking buffer $(0.3 \%$ Triton X-100 and 3\% goat serum in PBS) for $30 \mathrm{~min}$, followed by an overnight incubation with primary antibodies to tyrosine hydroxylase (rabbit polyclonal anti-TH, 1:500; Pel-Freeze Biologicals, Rogers, AR), glial fibrillary acidic protein (rabbit polyclonal anti-GFAP, 1:50; Biomeda, Foster City, CA), or microglia (rat monoclonal anti-Mac-1, 1:50; Boehringer Mannheim, Indianapolis, IN) in blocking buffer at $4^{\circ} \mathrm{C}$. Sections were then washed three times for 10 min each with PBS and incubated in biotinylated anti-rabbit IgG to detect TH and GFAP (1:200; Vector Laboratories, Burlingame, CA) or rat IgG to detect Mac-1 (1:200; Amersham) for $2 \mathrm{hr}$ at room temperature. Sections were washed and then incubated in ExtraAvidin (1:200; Sigma, St. Louis, MO) for $1 \mathrm{hr}$ at room temperature. Sections were washed and processed with $0.05 \% 3,3^{\prime}$-diaminobenzidine tetrachloride (Sigma) with $0.003 \% \mathrm{H}_{2} \mathrm{O}_{2}$. After processing, sections were washed, mounted on coated slides, dried, dehydrated through graded alcohols, cleared in xylene, and coverslipped in DPX mountant medium (Electron Microscopy Sciences, Fort Washington, PA).

Double immunolabeling. Young mice lesioned with MPTP and killed at $8 \mathrm{~d}$ along with saline-matched control were processed for combined fluorescence immunocytochemistry for IL-1 $\alpha$ (rabbit polyclonal antimouse IL-1 $\alpha$, 1:400; Genzyme, Cambridge, MA) and GFAP (mouse monoclonal anti-GFAP, 1:50; Boehringer Mannheim), IL-1 $\alpha$ and Mac-1, IL- $1 \alpha$ and Neu N (mouse monoclonal anti-neuronal nuclei, 1:500; Chemicon International, Temecula, CA), and IL-1 receptor (rat monoclonal anti-IL-1 receptor, 1:400; Genzyme) and TH. Sections were incubated in blocking buffer $(0.1 \%$ saponin and $3 \%$ goat serum in PBS) for $30 \mathrm{~min}$, followed by an overnight incubation of primary antibody in blocking buffer at $4^{\circ} \mathrm{C}$. IL- $1 \alpha$ was visualized by incubation with antirabbit IgG directly conjugated to fluorescein (1:200; Vector Laboratories), whereas GFAP, Mac-1, and Neu N immunoreactivity was reacted to appropriate biotinylated secondary antibodies [anti-mouse $\operatorname{IgG}$ to detect GFAP and Neu N (1:200; Vector Laboratories) and anti-rat IgG to detect Mac-1 (1:200; Amersham)] for $2 \mathrm{hr}$ followed by incubation in streptavidin conjugated to rhodamine (1:500; Molecular Probes, Eugene, OR). For IL-1 receptor and TH immunoreactivity, TH was visualized by incubation with anti-rabbit $\operatorname{IgG}$ directly conjugated to fluorescein, whereas IL-1 receptor was reacted to biotinylated anti-mouse $\operatorname{IgG}$ for 2 $\mathrm{hr}$ followed by incubation in streptavidin conjugated to rhodamine. After processing, sections were mounted on coated slides, dried, and coverslipped in Permafluor (Lipshaw, Pittsburgh, PA) mounting medium.

Retrograde labeling. To detect degeneration of dopaminergic neurons after MPTP lesion and to identify the cellular origin of the sprouted fibers in the dorsal striatum, we used young mice before MPTP lesion or treated after $30 \mathrm{~d}$ with saline and MPTP, respectively. Animals were anesthetized with avertin at $287.5 \mathrm{mg} / \mathrm{kg}$ (stock of 2,2,2-tribromoethanol at $12.5 \mathrm{mg} / \mathrm{ml}$; Aldrich, Milwaukee, WI), injected intraperitoneally. The mice were placed on a stereotaxic device (David Kopf Instruments, Tunjunga, CA). A burr hole was drilled on the right side of the skull to accommodate injection. Stereotaxic injections of $0.35 \mu \mathrm{l}$ of fluorescent latex microsphere "beads," a retrograde neuronal tracer (Lumafluor Inc., Naples, FL), were made into the dorsal striatum using a $1 \mu$ l Hamilton syringe (Hamilton, Reno, NE). Coordinates were located $2.7 \mathrm{~mm}$ caudal to the frontal nasal suture, $2.0 \mathrm{~mm}$ lateral from the midline suture, and $2.5 \mathrm{~mm}$ from the surface of the brain. The injection was made at a rate of $\sim 0.05 \mu \mathrm{l} / \mathrm{min}$, and the needle was left in place for $5 \mathrm{~min}$ after injection. By volumetric measurement, $\sim 10 \%$ of the lesioned area in the dorsal striatum received injections of microspheres. To detect degeneration of dopaminergic neurons, we killed the animals $8 \mathrm{~d}$ after MPTP lesion $(n=$ 3 /group) and processed the animals for TH and Mac-1 immunoreactivity. TH and Mac-1 were visualized by incubation with anti-rabbit and anti-rat $\mathrm{IgG}$ directly conjugated to fluorescein, respectively, and were visualized with a laser scanning confocal microscope (LSM 410; Zeiss, Oberkochen, Germany). To identify the cellular origin of the sprouted fibers in the dorsal striatum 1 month after the lesion, we killed animals $7 \mathrm{~d}$ after tracer injection $(n=5 /$ group $)$ and processed the animals for TH immunoreactivity that was visualized by incubation with anti-rabbit IgG directly conjugated to fluorescein.

Intrastriatal stab wound. Male C57BL6 mice (Harlan Sprague Dawley) at 8 weeks (young-adults) and 8 months (middle-aged) of age were anesthetized with avertin at $287.5 \mathrm{mg} / \mathrm{kg}$, injected intraperitoneally. The mice were placed on a stereotaxic device. A burr hole was drilled on the right side of the skull, and a $1 \mu \mathrm{l}$ Hamilton syringe was placed into the dorsal striatum. Coordinates were located $2.7 \mathrm{~mm}$ caudal to the frontal nasal suture, $2.0 \mathrm{~mm}$ lateral from the midline suture, and $2.5 \mathrm{~mm}$ from the surface of the brain. The needle was left in place for $5 \mathrm{~min}$. Animals were killed at 4 and $8 \mathrm{~d}$ after the lesion $(n=4-5 /$ group $)$.

Isolation of $c D N A$ clones. The IL- $1 \alpha$ and IL- $1 \beta$ cDNA clones were generously provided by Dr. A. Shaw of Glaxo from which 400 and 200 base pair fragments were subcloned into vector pGEM, respectively. The acidic FGF (aFGF) cDNA clone was isolated by PCR of mouse striatal cDNA from which a 350 base pair fragment corresponding to nucleotides 33-384 was subcloned into Bluescript II. The bFGF cDNA clone was 
generously provided by Dr. S. Shimasaki from which a 479 base pair fragment corresponding to nucleotides 525-1004 was subcloned into vector Bluescript $/ \mathrm{SK}^{+}$. The glial cell line-derived neurotrophic factor (GDNF) cDNA clone was isolated by PCR of rat genomic DNA from which a 414 base pair PCR DNA fragment was subcloned into Bluescript II.

Quantitative solution hybridization nuclease protection assay. Unlabeled sense and high specific activity $\left(\sim 1 \times 10^{9} \mathrm{cpm} / \mu \mathrm{g}\right){ }^{32} \mathrm{P}$-labeled antisense RNAs were transcribed. A standard curve of $0-10 \mu \mathrm{l}$ of $100 \mathrm{fg} / \mu \mathrm{l}$ sense RNA was used for quantitation. The standard and known amounts of cytoplasmic RNA isolated were hybridized with $\sim 200 \mathrm{pg}$ of antisense ${ }^{32} \mathrm{P}$-labeled RNA probe. Samples were heat-denatured at $85^{\circ} \mathrm{C}$ for $5 \mathrm{~min}$ and hybridized overnight at $45^{\circ} \mathrm{C}$. After hybridization, samples were RNase A- $(5 \mu \mathrm{g} / \mathrm{ml})$ and RNase T1- $(2 \mu \mathrm{g} / \mathrm{ml})$ treated for $1 \mathrm{hr}$ at $30^{\circ} \mathrm{C}$, followed by proteinase $\mathrm{K}(0.167 \mathrm{mg} / \mathrm{ml})$ digestion at $37^{\circ} \mathrm{C}$ for $15 \mathrm{~min}$. Samples were phenol and chloroform extracted, precipitated, resuspended in $1 \times$ Tris-EDTA, and electrophoresed on a nondenaturing 5\% acrylamide gel. Gels were dried and quantitated by phosphorimage analysis. Results were determined by linear regression analysis from the standard curve and presented as amoles of mRNA/ $\mu \mathrm{g}$ of total RNA.

Statistical analysis. Significant differences in IL-1 $\alpha$, IL-1 $\beta$, aFGF, bFGF, and GDNF mRNA levels between control and MPTP treatment groups were analyzed using ANOVA followed by Fisher's protected least significant difference post hoc analysis. The level of significance was set at $p<0.05$.

\section{RESULTS}

Young mice have the ability to recover after MPTPinduced toxicity of dopaminergic neurons, whereas middle-aged mice do not

Neurochemical assessment

High-affinity synaptosomal dopamine uptake is a sensitive quantitative indicator of dopaminergic axonal terminal density. As shown in Figure 1, determination of dopamine uptake at various times after MPTP treatment revealed an initial comparable loss in dopamine uptake levels in both age groups in the dorsal as well as in the ventral striatum. In the dorsal striatum, we found that MPTP produced a significant reduction in dopamine uptake levels at $4 \mathrm{~d}$ after MPTP in young and middle-aged mice (59 and $41 \%$ of control, respectively; Fig. $1 A$ ). A reduction in dopamine uptake levels in the dorsal striatum was still observed at 8 and $14 \mathrm{~d}$ in both age groups. However, between 14 and $30 \mathrm{~d}$, a significant recovery in dopamine uptake levels was observed in young mice. Dopamine uptake levels increased to $87 \%$ of control levels after MPTP treatment in the dorsal striatum of young mice, whereas older mice did not exhibit such recovery. Thus, we found, in accordance with others (Ricaurte et al., 1987a), that young mice but not middle-aged mice showed substantial recovery of striatal dopaminergic nerve terminals in the dorsal striatum within 1 month.

Because it has been thought that recovery in the dorsal striatum could arise from spared fibers in the ventral striatum (Gilad and Reis, 1979; Hansen et al., 1995; Blanchard et al., 1996), it was important to determine whether the loss and recovery of dopamine uptake levels in the ventral striatum differ between young and middle-aged animals after MPTP treatment. In the ventral striatum, we observed that MPTP produced a significant reduction in dopamine uptake levels at 4 and $8 \mathrm{~d}$ in both young and middle-aged mice (Fig. $1 B$ ). In young mice, dopamine uptake levels in the ventral striatum recovered between 8 and $30 \mathrm{~d}$ after MPTP treatment, increasing to a level that was greater than that of control values at 14 and $21 \mathrm{~d}$ (111 to $137 \%$ of control, respectively). By $30 \mathrm{~d}$ after MPTP treatment, dopamine uptake levels returned to $85 \%$ of control levels in young mice. In middle-aged mice treated with MPTP, recovery of dopamine uptake levels was also seen in the ventral striatum. The recovery occurred 1 week later compared with that in young mice between 14 and $30 \mathrm{~d}$.
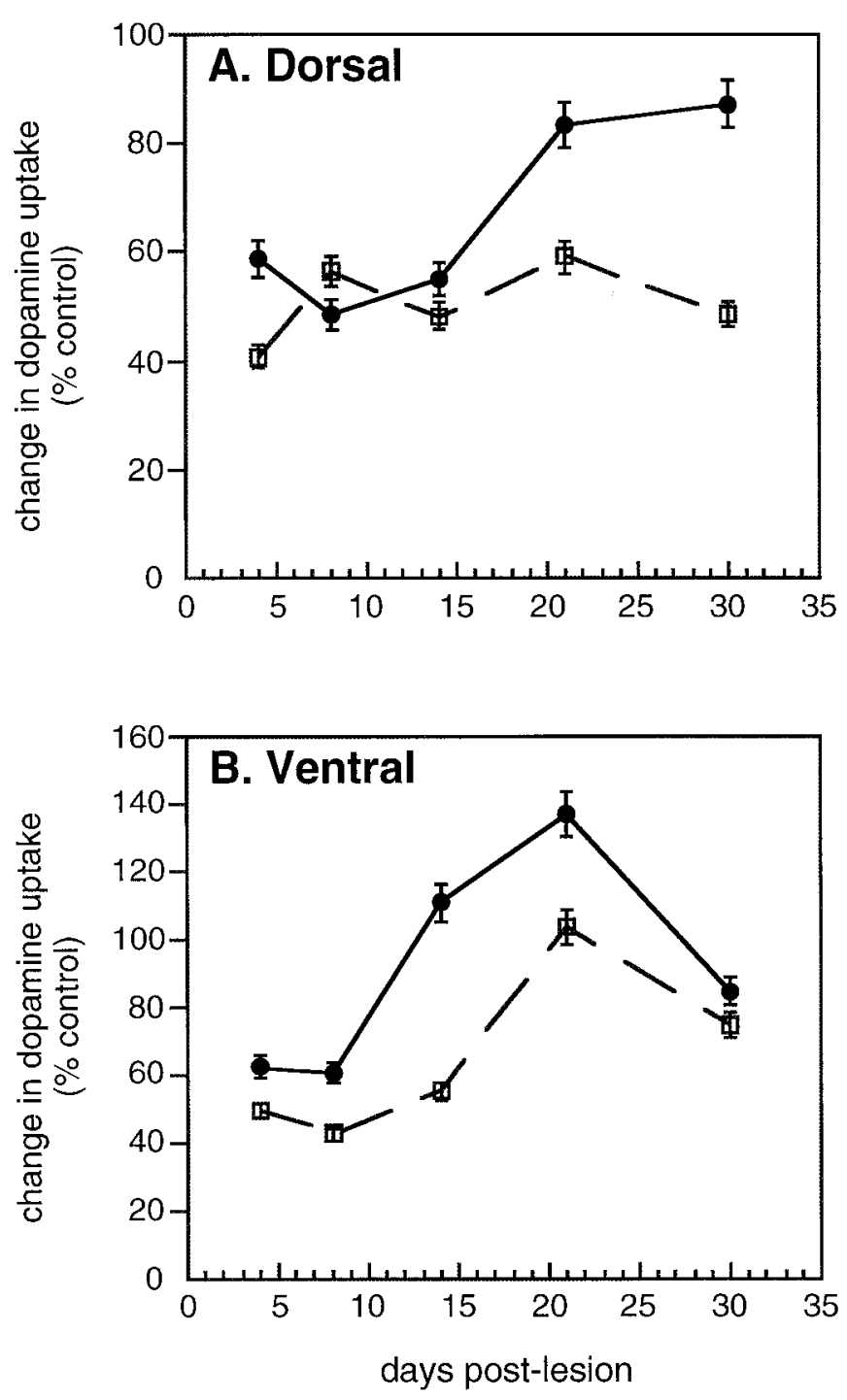

Figure 1. $[3 \mathrm{H}]$ Dopamine uptake after MPTP treatment in the dorsal $(A)$ and ventral $(B)$ striatum of young and middle-aged mice at $4,8,14$, 21 , and $30 \mathrm{~d}$ after the lesion. Values are presented as the change in dopamine uptake (expressed as percent of control \pm SEM) for $n=4-5$ animals per group. The solid line represents young mice treated with a single dose of MPTP at $55 \mathrm{mg} / \mathrm{kg}$, and the dotted line represents middleaged mice treated with a single dose of MPTP at $40 \mathrm{mg} / \mathrm{kg}$.

Similar to young mice, middle-aged mice showed a greater increase in dopamine uptake levels at $21 \mathrm{~d}$ compared with levels observed at $30 \mathrm{~d}$ after the lesion. The recovery in dopamine uptake levels in the ventral striatum exhibited by both age groups in which the increase was greater than that of control levels after MPTP treatment suggests that there may be a transient increase in the affinity or the number of dopamine uptake sites per terminal.

\section{Morphological assessment}

An antibody directed to TH, an enzyme involved in dopamine biosynthesis, is a marker for catecholamine neurons. TH immunocytochemistry revealed a marked disappearance of $\mathrm{TH}$ immunoreactive (TH-IR) fibers in the dorsal striatum of both young and middle-aged mice as early as $4 \mathrm{~d}$ after MPTP treatment (Fig. 2B, $G$ ), compared with that in age-matched controls 


\section{YOUNG}

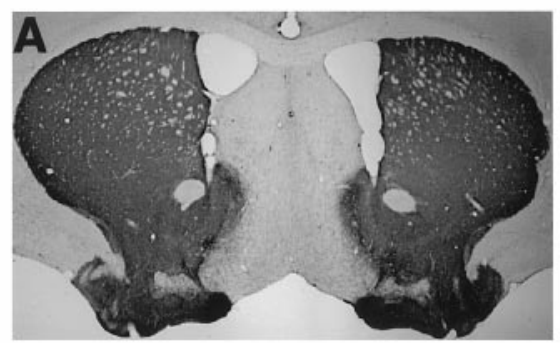

saline

$4 \mathrm{~d}$

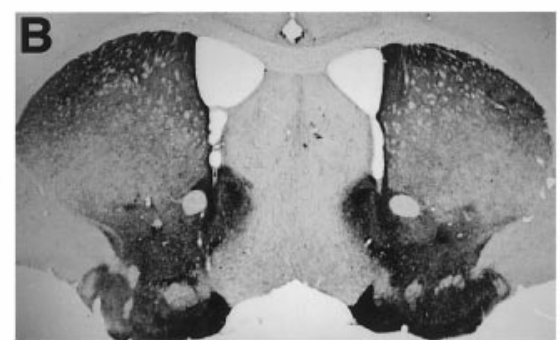

$8 \mathrm{~d}$
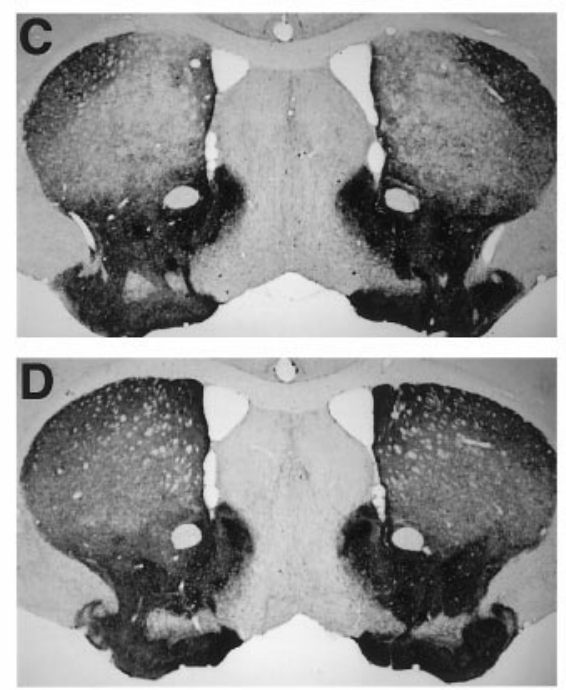

$14 \mathrm{~d}$

$30 \mathrm{~d}$

\section{MIDDLE-AGED}
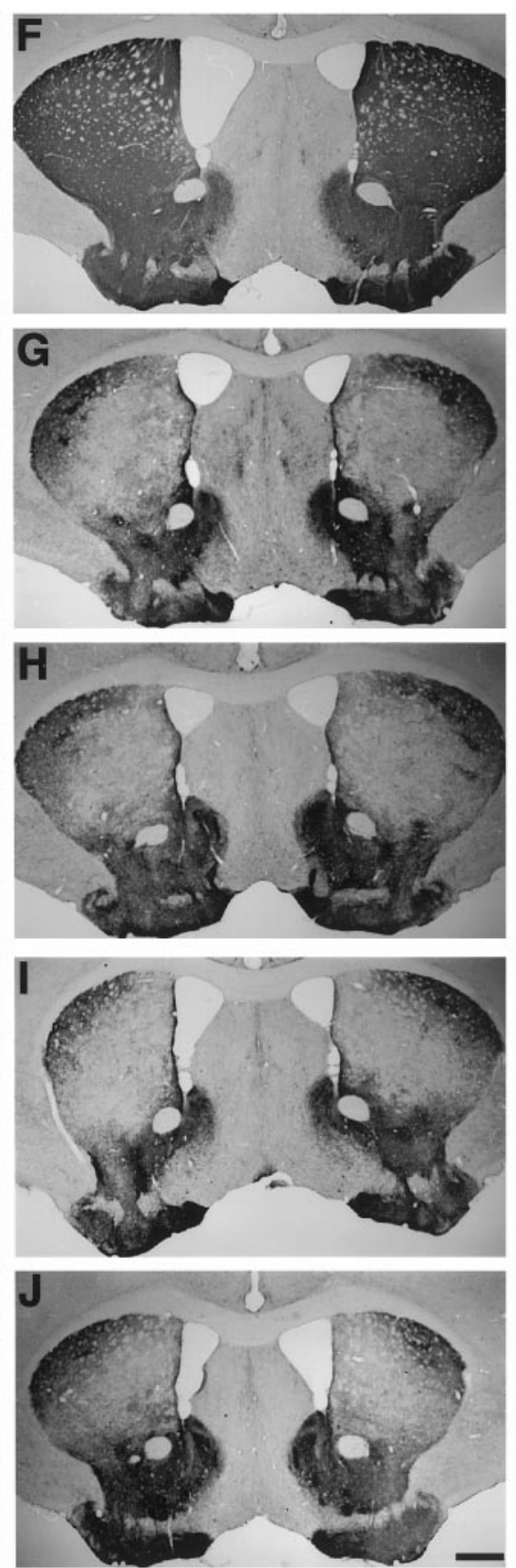

Figure 2. TH immunocytochemistry in the striatum of young $(A-E)$ and middleaged $(F-J)$ mice after saline treatment and MPTP treatment at $4,8,14$, and 30 d. MPTP caused a marked disappearance of TH-IR fibers in the dorsal striatum of both age groups; however a progressive recovery of TH-IR fibers was observed between 14 and $30 \mathrm{~d}$ after MPTP treatment $(D, E)$ in young mice compared with that in middle-aged mice that did not show such apparent recovery. Scale bar, $500 \mu \mathrm{m}$.
(Fig. $2 A, F)$. No marked reduction in TH-IR fibers was seen in the ventral striatum of young mice after MPTP treatment. However, in middle-aged mice, a modest reduction in TH-IR fibers was observed in the ventral striatum compared with that in saline-treated animals at $4 \mathrm{~d}$ after MPTP treatment that appeared to recover in $\mathrm{TH}$ expression at later time points. A significant loss of TH-IR fibers in the dorsal striatum was still observed at $8 \mathrm{~d}$ after MPTP treatment in both age groups (Fig. $2 C, H)$. However, in the dorsal striatum of young mice, a progressive recovery of TH-IR fibers was observed starting at $14 \mathrm{~d}$ (Fig. $2 D$ ), reaching a nearly normal staining pattern by $30 \mathrm{~d}$ after
MPTP treatment (Fig. 2E). In contrast, middle-aged mice did not show such an apparent recovery (Fig. 2I,J).

\section{Dopaminergic cell loss after MPTP treatment}

To examine the neurodegenerative effects of MPTP on dopaminergic cell bodies in young and middle-aged mice, we assessed midbrain sections immunostained with $\mathrm{TH}$ antiserum. TH immunocytochemistry revealed a significant depletion of TH-IR cell bodies in the $\mathrm{SN}$ of both age groups as early as $4 \mathrm{~d}$ after MPTP treatment (Fig. $3 B, G$ ). In contrast, no marked reduction in TH-IR cell bodies was seen in the VTA compared with that in 
age-matched controls (Fig. 3A,F). A significant loss of TH-IR cells in the SN remained evident weeks after MPTP treatment in both age groups (Fig. $3 C-E, H-J$ ). At $30 \mathrm{~d}$ after MPTP treatment, although a significant depletion of TH-IR cells was found compared with that in saline-treated animals, a modest return of $\mathrm{TH}$ expression in the $\mathrm{SN}$ was observed in young mice (Fig. $3 E$ ). This result indicates that in young mice, some of the dopaminergic neurons may survive the MPTP insult and the transient decrease in $\mathrm{TH}$ expression returns as reported by other investigators (Kitt et al., 1986; Sundström et al., 1988).

The use of TH-IR neuronal counts has not been a reliable method to measure for MPTP-induced degeneration of dopaminergic neurons. It was shown that MPTP can cause a loss in TH expression without producing neuronal death (Jackson-Lewis et al., 1995). To determine whether SN dopaminergic neurons are in fact degenerating after MPTP treatment, we prelabeled SN cells with fluorescent microspheres in young mice before MPTP administration. Young mice were used because they have been suggested to be less sensitive to MPTP-induced toxicity than are middle-aged mice (Ricaurte et al., 1986). The animals were killed $8 \mathrm{~d}$ after saline and MPTP treatment, and midbrain sections were reacted with antibodies to $\mathrm{TH}$ and Mac-1, a microglia marker specific for the mouse (Springer et al., 1979; Beller et al., 1982). In saline-treated mice, retrogradely transported fluorescent microspheres labeled the cell body of a subpopulation of TH-IR neurons in the $\mathrm{SN}$ (Fig. 4A,B). In MPTP-treated mice, although some fluorescent microspheres were found in TH-IR neurons, they were also found to be aggregated and scattered throughout the SN (Fig. 4C). Mac-1-IR cells with internalized fluorescent microspheres were found at the level of the $\mathrm{SN}$ cell bodies, suggesting that microglia are phagocytosing degenerating SN dopaminergic neurons (Fig. 4D).

\section{Collateral sprouting of dopaminergic terminals arises from the VTA}

To identify the cellular origin of the sprouted fibers in the dorsal striatum of young mice after MPTP-induced injury, we injected fluorescent microspheres into the dorsal striatum of saline- and MPTP-treated animals at $30 \mathrm{~d}$ after the lesion when recovery of dopamine uptake levels and TH-IR fibers was observed (Fig. $5 A, D)$. The animals were killed $7 \mathrm{~d}$ after tracer injection, and the midbrain was reacted with the antibody to TH. In saline-treated mice, we found a majority $(95 \pm 0.595 \%)$ of cells retrolabeled with microspheres colocalized with TH-IR neurons in the SN (Fig. 5B,C). In MPTP-treated mice, we observed $87 \pm 1.231 \%$ of cells retrolabeled with microspheres colocalized with TH-IR neurons in the VTA, thus suggesting that recovery of the dorsal striatum is mainly attributable to collateral sprouting of axonal fibers in the ventral striatum (Fig. $5 E, F$ ). However, because the injection of the retrograde tracer was made to a localized area and does not represent the entire dorsal striatum, we cannot exclude that remaining SN dopaminergic neurons can also contribute to compensatory sprouting in the denervated striatum.

\section{Glial activation}

MPTP produces a glial reaction in young mice after MPTP treatment (Francis et al., 1995; Czlonkowska et al., 1996). However, glial responses after MPTP have not been investigated in middle-aged mice. Furthermore, studies have shown that the reactive glial response to neuronal injury slows with age (Hoff et al., 1982a,b; Goss et al., 1991). To investigate whether there were differences in glial responses in young compared with middle- aged mice after MPTP treatment, we reacted striatum and midbrain sections at various times after the lesion with antibodies to Mac-1 and GFAP.

\section{Microglial reaction}

Induction of a microglial reaction in the denervated striatum (confined mainly to dorsal striatum) and the midbrain (confined at the level of the dopaminergic cell bodies in the SN) was seen as early as $4 \mathrm{~d}$ after the lesion in both age groups compared with age-matched controls (Fig. 6). A difference in the morphology of microglial cells as compared with that in an age-matched control was observed in both young and middle-aged mice. In MPTPtreated mice, the microglia exhibited stronger Mac-1 labeling, larger cell bodies, and thicker, less ramified processes compared with that in saline-treated animals (see Fig. 9H). In young mice, maximal activation of microglial cells in the striatum was observed at $8 \mathrm{~d}$ after the lesion, and by $14 \mathrm{~d}$, activated microglial cells were no longer found (Fig. $6 C, D$ ). In middle-aged mice, maximal activation of microglial cells in the striatum was observed at $4 \mathrm{~d}$ after the lesion (Fig. $6 F$ ); by 8 and $14 \mathrm{~d}$, a modest activation of microglial cells was still visible (Fig. $6 G, H$ ). In the midbrain, the peak of change in microglial reaction also occurred faster in middle-aged mice, as early as $4 \mathrm{~d}$ after the lesion compared with young mice in which the peak change was observed at $8 \mathrm{~d}$ (Fig. 6I-K, $M-O$ ). By $14 \mathrm{~d}$, activated microglial cells in the midbrain of young mice were no longer found; however, some scattered activated microglial cells were still seen in the midbrain of middle-aged mice (Fig. $6 L, P$ ).

\section{Astroglial reaction}

In both age groups compared with age-matched controls, immunolabeling for GFAP was dramatically increased in the striatum and midbrain as early as $4 \mathrm{~d}$ after the lesion (Fig. 7). GFAP-IR astrocytes became hypertrophic, and they exhibited an enlarged cell body and shortened, swollen processes (see Fig. 9F). Maximal activation of astroglial cells in the striatum and midbrain occurred faster in middle-aged mice, as early as $4 \mathrm{~d}$ after the lesion (Fig. $7 F, N)$, compared with young mice in which peak changes were observed at $8 \mathrm{~d}$ (Fig. $7 C, K$ ). By $14 \mathrm{~d}$, GFAP-IR cells were no longer observed in the striatum of young mice (Fig. $7 D$ ); however, an increase in GFAP-IR cells remained distributed in the striatum of middle-aged mice (Fig. $7 H$ ). In the midbrain, a modest induction of hypertrophic astrocytes was still found at $14 \mathrm{~d}$ after MPTP treatment in both age groups (Fig. 7L,P). These results indicate that differences in glial reaction after MPTP exist between young and middle-aged mice and that the reactive glial response was not delayed with age. In fact, middleaged mice produced a faster and sustained glial response for 2 weeks compared with that in young mice after MPTP treatment.

\section{Induction of IL-1 mRNA is correlated with compensatory sprouting in the denervated striatum of young mice}

IL-1 exists in two structurally distinct forms, IL- $1 \alpha$ and IL- $1 \beta$, both of which recognize the same receptor and have similar biological activities (March et al., 1985). To determine whether IL-1 is regulated in response to MPTP and to examine whether age influences the regulation of IL-1, we analyzed tissues from the same animals used for dopamine uptake analysis for IL- $1 \alpha$ and IL- $1 \beta$ mRNA changes by RNase protection assay. As a positive control for IL- $1 \alpha$ and IL- $1 \beta$ changes after MPTP treatment, total RNA from intrastriatal stab wounds of both age 
YOUNG

Saline
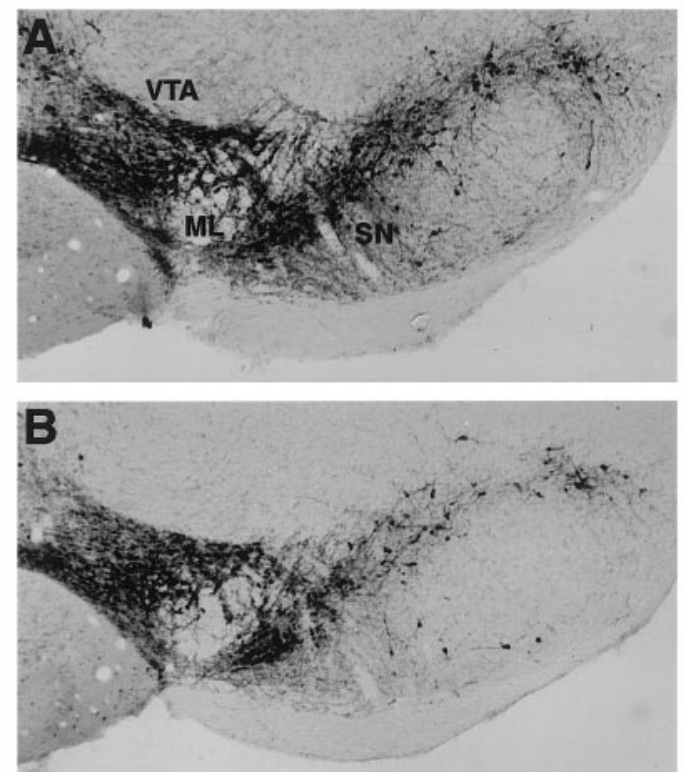

$4 \mathrm{~d}$

$8 \mathrm{~d}$

$14 \mathrm{~d}$
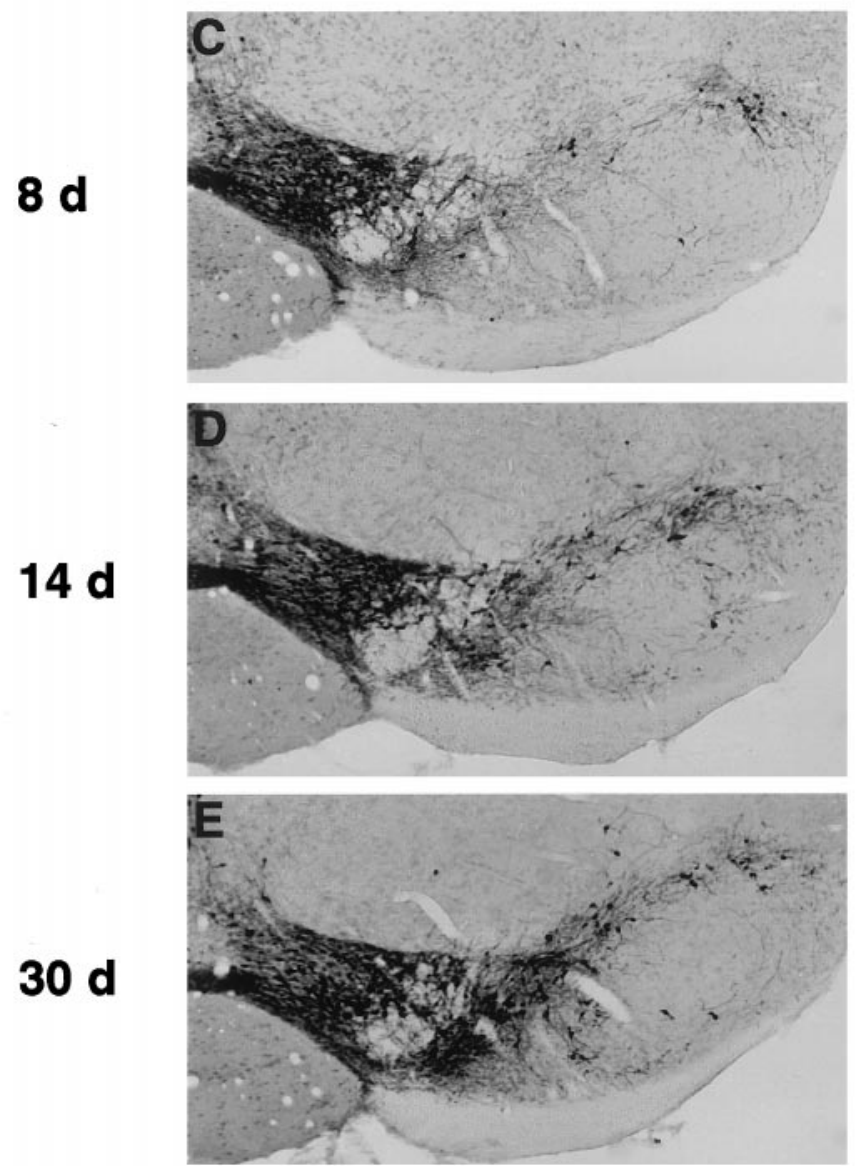

MIDDLE-AGED
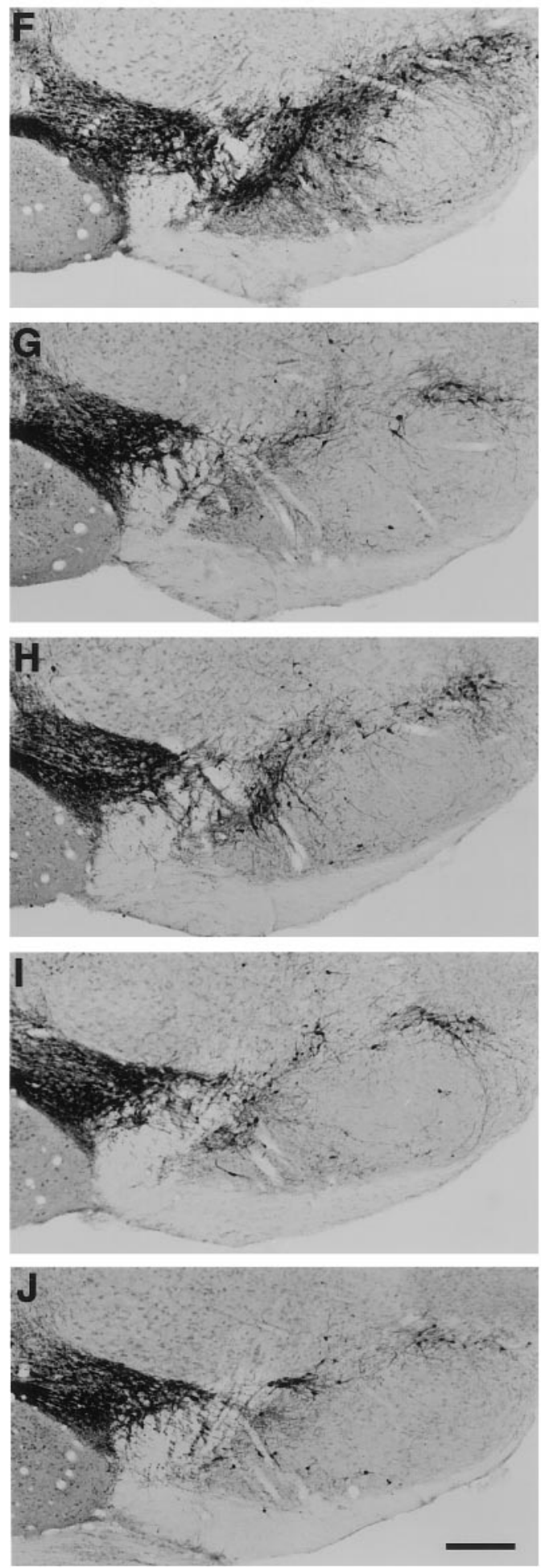

Figure 3. TH immunocytochemistry in the midbrain of young $(A-E)$ and middle-aged $(F-J)$ mice after saline treatment and MPTP treatment at 4,8 , 14, and $30 \mathrm{~d}$. MPTP produced a significant loss of TH-IR cell bodies in the SN but not in the VTA of both age groups compared with that in age-matched controls $(A, F)$. Scale bar, $200 \mu \mathrm{m}$. 

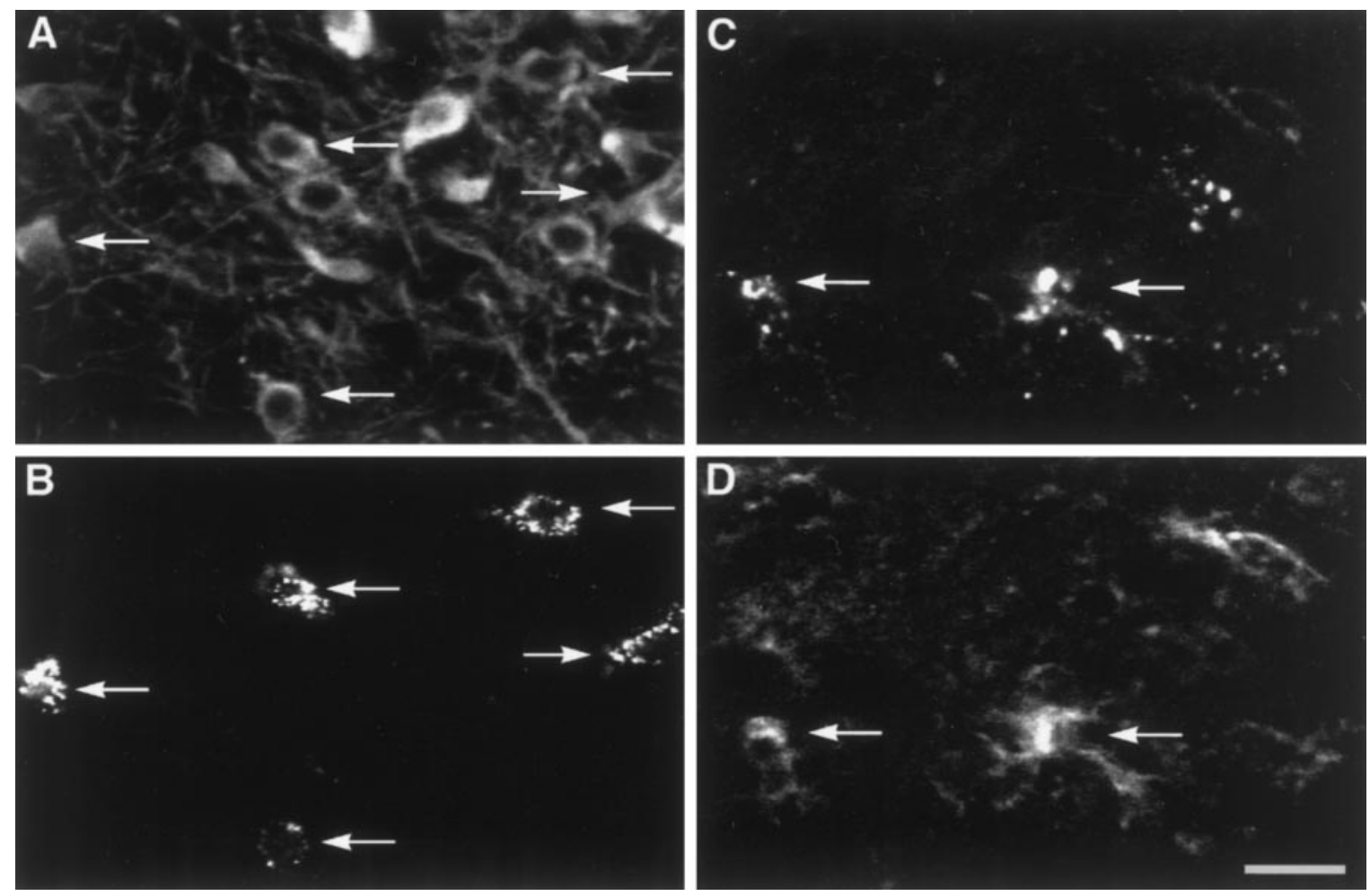

Figure 4. Dopaminergic neuronal degeneration in young mice at $8 \mathrm{~d}$ after MPTP treatment. $A, B$, Confocal images of TH-IR cell bodies $(A)$ in the SN retrogradely labeled with microspheres $(B)$ in a saline-treated animal. Arrows are in register and show the same location within the same field of view for $A$ and $B$, indicating that labeled microspheres are within TH-IR cell bodies. $C, D$, Confocal images showing the distribution of labeled microsphere aggregates $(C)$ and Mac-1-IR microglial cells $(D)$ within the SN of a MPTP-treated animal. Arrows are in register and show the same location within the same field of view for $C$ and $D$, indicating that Mac-1-IR microglial cells are internalizing the labeled microspheres and suggesting that they are phagocytosing degenerating dopaminergic neurons. Scale bar, $25 \mu \mathrm{m}$.

groups was used because both the $\alpha$ and the $\beta$ forms have been shown to increase after stab injury (Giulian and Lachman, 1985).

In the dorsal striatum of young mice after MPTP treatment, IL- $1 \alpha$ mRNA was significantly increased at $4 \mathrm{~d}$ and was maximally induced at $8 \mathrm{~d}$ after the lesion (518\% of control; Fig. $8 A$ ). After $14 \mathrm{~d}, \mathrm{IL}-1 \alpha$ mRNA remained significantly elevated, and by $30 \mathrm{~d}$, IL-1 $\alpha$ returned to control levels in the dorsal striatum of young mice. In the dorsal striatum of middle-aged mice after MPTP treatment, only a modest increase was observed at 4 and $8 \mathrm{~d}$ after the lesion (130 and $135 \%$ of control, respectively; Fig. $8 B)$. After $14 \mathrm{~d}$, IL- $1 \alpha$ returned to control levels in the dorsal striatum of middle-aged mice after MPTP treatment. Activation of IL- $1 \alpha$ synthesis in response to intrastriatal stab injury was similar in both age groups. Young mice that received intrastriatal stab wound injury revealed 306 and $287 \%$ of the control induction at 4 and $8 \mathrm{~d}$ after the lesion, respectively (Fig. $8 A$ ). Similarly, middle-aged mice revealed 252 and $192 \%$ of the control increase at 4 and $8 \mathrm{~d}$ after the lesion, respectively, after stab injury (Fig. $8 B)$. These results indicate that the ability to induce IL- $1 \alpha$ synthesis in the dorsal striatum after MPTP dramatically declines with age; however, this strictly depends on the nature of the injury.

Similar to the induction seen in the dorsal striatum of young MPTP-treated mice, an increase in IL- $1 \alpha$ mRNA in the ventral striatum was also seen at $4 \mathrm{~d}$ and was maximal at $8 \mathrm{~d}$ after the lesion (501\% of control; Fig. 8C). After 14 and 30 d, IL- $1 \alpha$ mRNA remained significantly elevated. However, in middle-aged mice, no changes in IL- $1 \alpha$ mRNA were observed in the ventral striatum (Fig. 8D). The enhanced and extended activation of IL-1 $\alpha$ synthesis seen both in the dorsal and ventral striatum of young but not middle-aged mice seems best to correlate with the time when MPTP-induced plastic changes are occurring in young mice.

Although significant changes in IL- $1 \alpha$ were observed after MPTP treatment, we did not observe any changes in IL- $1 \beta$ mRNA in either the dorsal or ventral striatum of either age group (data not shown). However, IL-1 $\beta$ mRNA was significantly increased in both age groups after intrastriatal stab wound injury. The selective activation seen in the $\alpha$ form but not the $\beta$ form after MPTP treatment suggests that the type of injury-induced damage to the brain may elicit a difference in the IL-1 response.

Because we found microglial activation and an astrocytic response at the site of degenerating cell bodies, we next evaluated whether there were changes in IL- $1 \alpha$ mRNA in the midbrain after MPTP lesion. In both age groups, no induction of IL- $1 \alpha$ mRNA was observed in the midbrain of MPTP-treated mice compared with age-matched controls (Fig. 8E,F). Instead, middle-aged mice exhibited a significant decrease in IL- $1 \alpha$ mRNA at 8 and $14 \mathrm{~d}$ after MPTP treatment (Fig. $8 F$ ). These results suggest that the activation of IL- $1 \alpha$ in response to MPTP is region specific.

\section{Cellular source of increased IL-1 $\alpha$ expression}

Activated microglia have been shown to be a principal source of IL-1, although there is evidence that astrocytes as well as neurons can synthesize IL-1 (Fontana et al., 1982; Giulian, 1987; Breder et al., 1988; Hetier et al., 1988; Lechan et al., 1990; Tchelingerian et al., 1993). To identify the cellular source of IL-1 $\alpha$ in our MPTPlesion model, we performed double-labeling immunocytochemistry on the striatum of young mice at $8 \mathrm{~d}$ after the lesion, when 

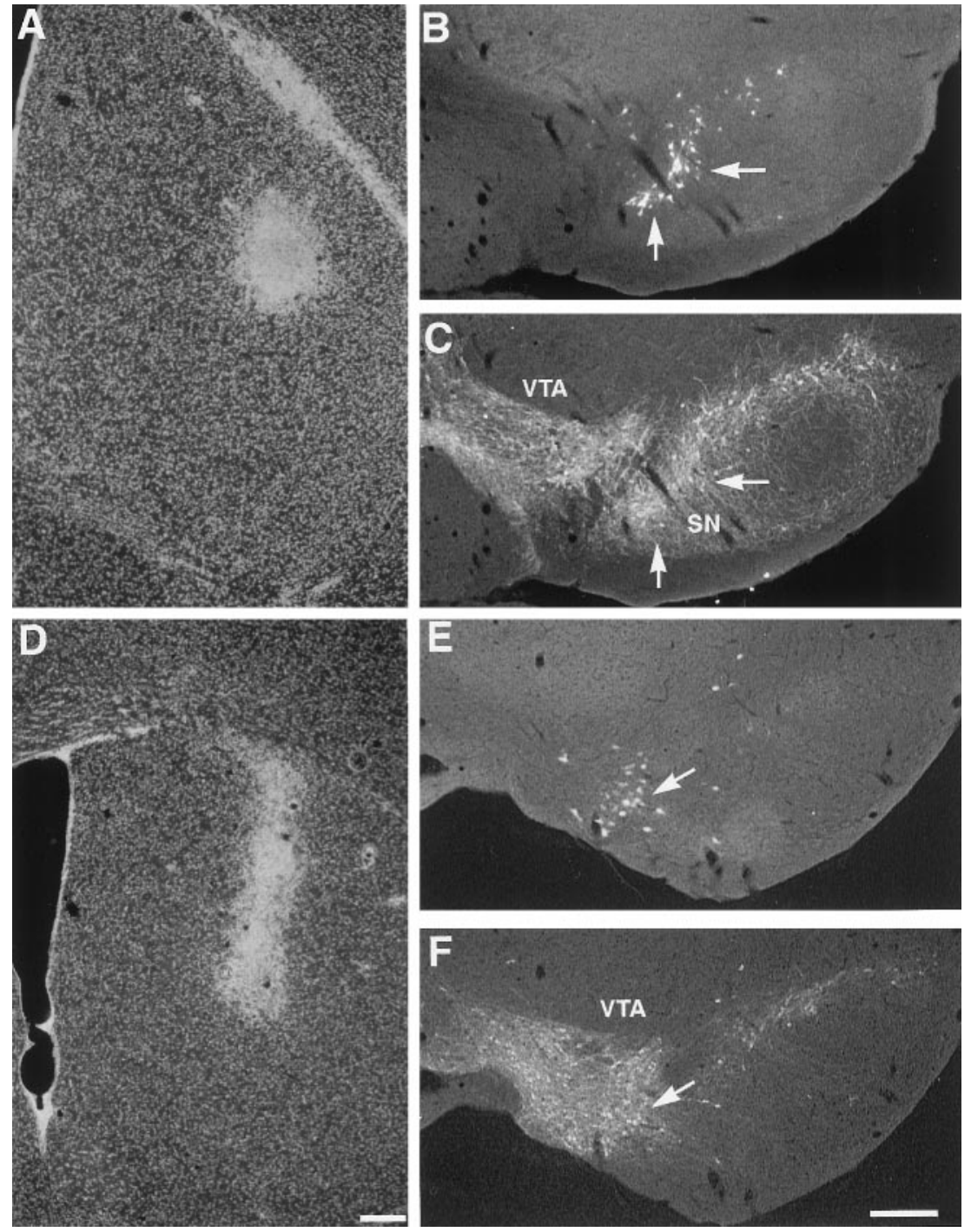

Figure 5. Collateral sprouting of dopaminergic axonal fibers arise from the VTA in young mice. $A, D$, Injection sites of fluorescent microspheres into the dorsal striatum of saline- $(A)$ and MPTP-treated $(D)$ mice are shown. $B, C$, In a saline-treated animal, fluorescent microspheres $(B)$ were found to colocalize with TH-IR neurons $(C)$ in the SN. $E, F$, In a MPTP-treated animal, fluorescent microspheres $(E)$ were found to colocalize with TH-IR neurons $(F)$ in the VTA, indicating that most of the sprouting fibers were arising from dopaminergic neurons in the VTA. Arrows are in register and show the same location within the same field of view. Scale bar, $200 \mu \mathrm{m}$.
IL- $1 \alpha$ mRNA was detected at its maximal level, using antibodies to IL- $1 \alpha$ in combination with either Neu N, a specific marker of neuronal nuclei, GFAP, or Mac-1. In saline-treated young mice, we found faint perinuclear localization of IL- $1 \alpha$ in Neu N-IR cells (Fig. 9A,B). However, in MPTP-treated mice, we observed perinuclear and cytoplasmic staining of IL- $1 \alpha$ in Neu N-IR cells (Fig. $9 C, D$ ) as well as colocalization of IL- $1 \alpha$ and GFAP-IR hypertrophic astrocytes scattered throughout the denervated striatum (Fig. 9E,F). Colocalization of IL-1 $\alpha$ and Mac-1-IR microglial cells was not observed in these MPTP-treated animals (Fig. $9 G, H)$. These results indicate that hypertrophic astrocytes and neurons are most likely the cellular sources of increased IL- $1 \alpha$ expression in the striatum of young mice after MPTP-induced lesion.

\section{No change in endogenous dopaminergic neurotrophic factor gene expression}

Because we and others have reported that intraventricular administration of IL-1 can induce neurotrophic factor gene expression (Spranger et al., 1990; Rivera et al., 1994; Ho and Blum, 1997), we wanted to examine whether changes in dopaminergic neurotrophic factor gene expression mediate the MPTP-induced plasticity of dopaminergic neurons. Among the trophic factors expressed in the brain, aFGF, bFGF, and GDNF are well-characterized do- paminergic neurotrophic factors that can enhance the sprouting of dopaminergic fibers after a neurotoxic damage and can be produced by astrocytes (Date et al., 1990b; Otto and Unsicker, 1990; Tomac et al., 1995). To investigate a potential role for these astroglia-derived dopaminergic neurotrophic factors in MPTPinduced plasticity of dopaminergic neurons, we quantified aFGF, bFGF, and GDNF mRNA in the striatum using RNase protection assay. No changes in aFGF and bFGF mRNA were found in the dorsal and ventral striatum of either age group (Fig. 10). In addition, no changes in GDNF mRNA were found in the dorsal striatum of young mice after MPTP treatment (Fig. 10C).

\section{Localization of IL-1 receptor in TH-IR neurons}

Because we observed an induction of IL- $1 \alpha$ in the striatum of young mice treated with MPTP and no change in any of the astroglia-derived dopaminergic neurotrophic factors analyzed, we examined whether IL- $1 \alpha$ could be acting directly on dopaminergic neurons to induce sprouting of axonal fibers. To assess this, we examined the expression of IL-1 receptor on these neurons. Double-labeling immunocytochemistry was performed in salineand MPTP-treated young mice at $8 \mathrm{~d}$ after the lesion with antibodies to IL-1 receptor and TH. In saline-treated mice, IL-1 receptor expression was colocalized with TH-IR cell bodies in the SN and VTA throughout the midbrain (Fig. 11A,B). After 
YOUNG MIDDLE-AGED
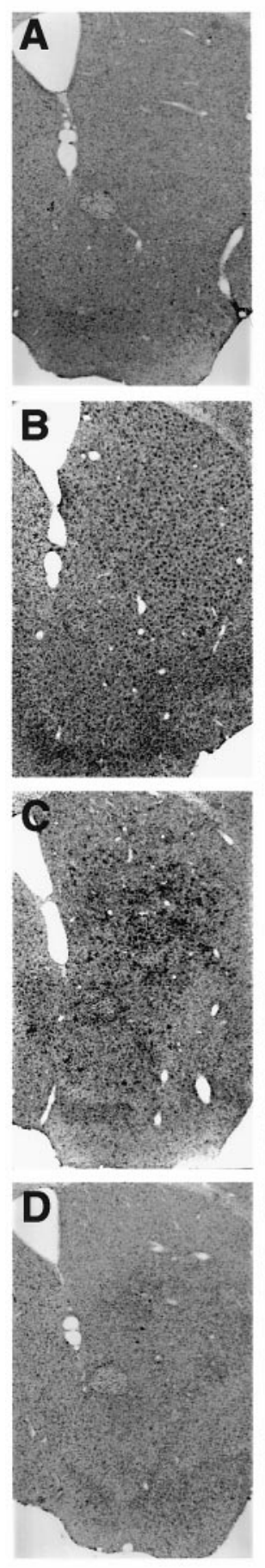
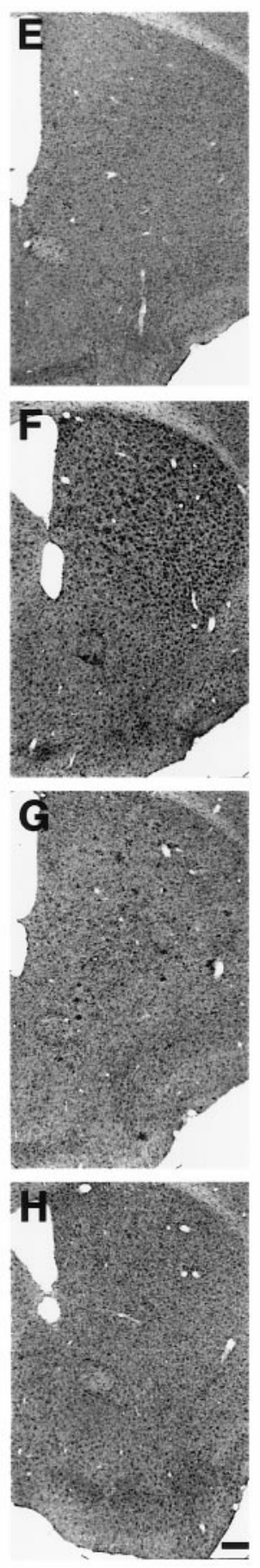

YOUNG
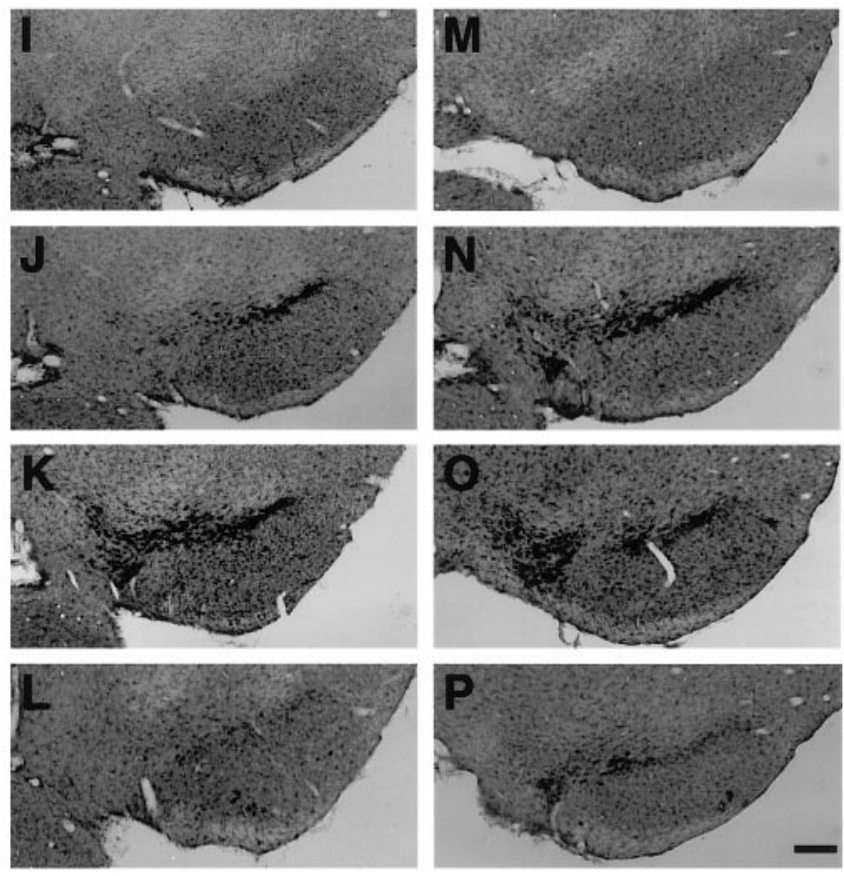

MIDDLE-AGED
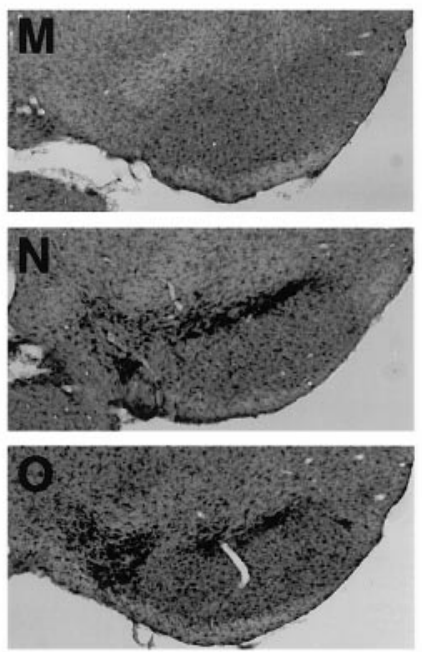

Figure 6. Microglial cells immunoreactive for Mac-1 in the striatum $(A-H)$ and midbrain $(I-P)$ of young and middle-aged mice after saline and MPTP treatment. $A$, $E$, Striatum of young and middle-aged saline-treated mice, respectively. $B-D, F-H$, Striatum of young and middle-aged mice at 4,8 , and $14 \mathrm{~d}$ after MPTP treatment, respectively. $I, M$, Midbrain of young and middle-aged saline-treated mice, respectively. $J-L, N-P$, Midbrain of young and middle-aged mice at 4,8 , and $14 \mathrm{~d}$ after MPTP treatment, respectively. Scale bar, $200 \mu \mathrm{m}$.

MPTP treatment, IL-1 receptor expression remained colocalized with TH-IR neurons in the VTA and scattered TH-IR cells in the SN (Fig. 11C,D). IL-1 receptor-positive/TH-negative profiles within the midbrain were also observed. These results indicate that IL- $1 \alpha$ may act as a target-derived neurotrophic factor that enhances the plasticity of dopaminergic fibers after MPTPinduced injury.

\section{DISCUSSION}

Our data are consistent with observations that young mice after MPTP treatment showed a significant recovery of dopaminergic nerve terminals in the dorsal striatum, whereas middle-aged mice did not. In this report, we demonstrated that spared dopaminergic neurons in the VTA were the predominant source of axonal afferents reinnervating the denervated striatum of young mice. Moreover, because significant recovery of dopamine uptake levels was observed in the ventral striatum of both age groups, this suggests that the lack of recovery in the dorsal striatum of middleaged mice is not attributable to greater damage of the ventral striatum. We found, in fact, that the inability of older mice to support collateral axonal outgrowth after MPTP lesion was best correlated with the lack of sustained induction of IL- $1 \alpha$ synthesis 
YOUNG MIDDLE-AGED
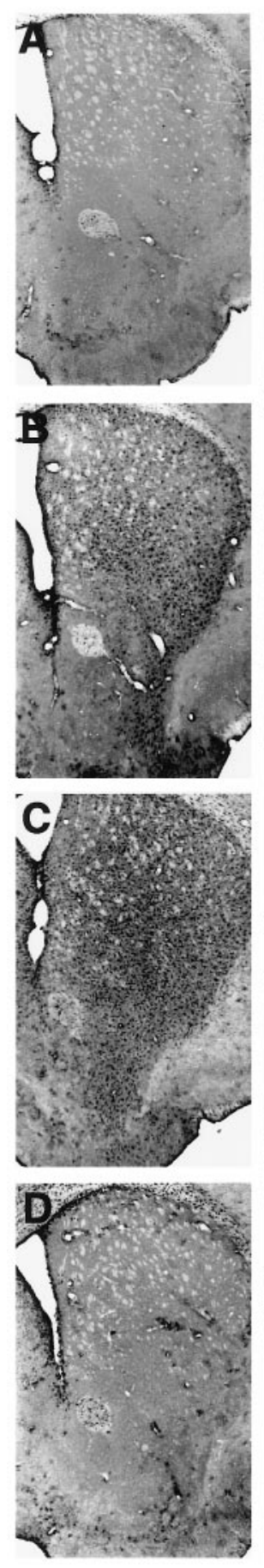
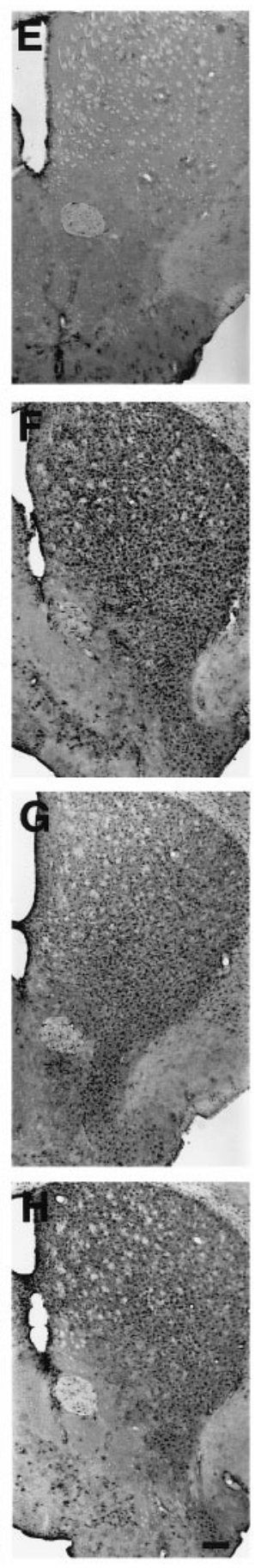

YOUNG
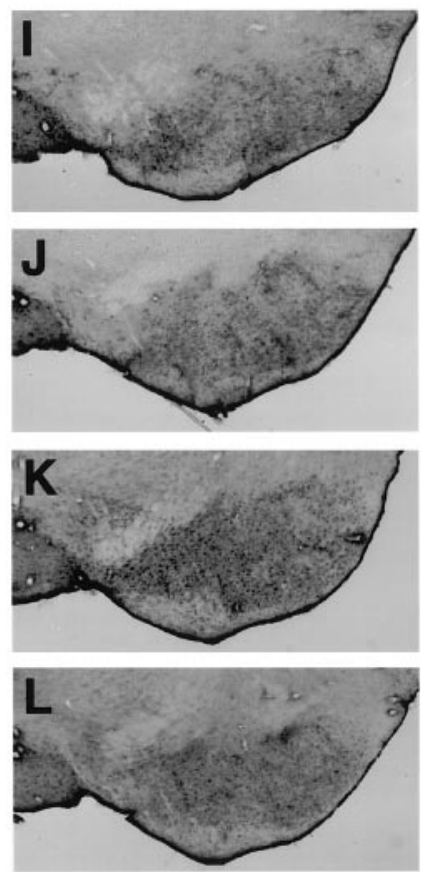

MIDDLE-AGED
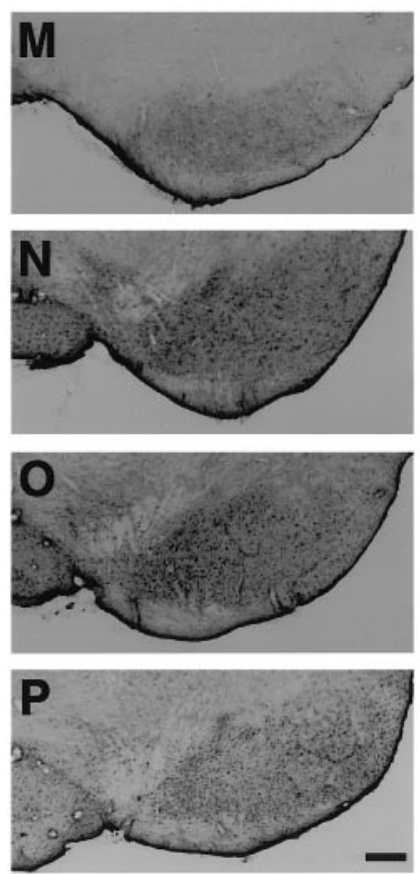

Figure 7. Astroglial cells immunoreactive for GFAP in the striatum $(A-H)$ and midbrain $(I-P)$ of young and middle-aged mice after saline and MPTP treatment. $A$, $E$, Striatum of young and middle-aged saline-treated mice, respectively. $B-D, F-H$, Striatum of young and middle-aged mice at 4,8 , and $14 \mathrm{~d}$ after MPTP treatment, respectively. $I, M$, Midbrain of young and middle-aged saline-treated mice, respectively. $J-L, N-P$, Midbrain of young and middle-aged mice at 4,8 , and $14 \mathrm{~d}$ after MPTP treatment, respectively. Scale bar, $200 \mu \mathrm{m}$.

in the dorsal and ventral striatum. Young mice displayed a maximal four- to fivefold greater induction of IL- $1 \alpha$ mRNA for an extended period of time in both the dorsal and ventral striatum compared with that in middle-aged mice, thus suggesting that IL- $1 \alpha$ could play an important role in MPTP-induced plasticity of dopaminergic neurons.

\section{Role for IL-1 $\alpha$ in compensatory dopaminergic sprouting after MPTP}

The time course of IL- $1 \alpha$ induction seen in the dorsal and ventral striatum of young mice directly correlated with the time period of MPTP-induced axonal changes. A progressive recovery of dopamine uptake levels and TH-IR fibers in the dorsal striatum of young mice was seen between 14 and $30 \mathrm{~d}$ after the lesion. Interestingly, our results show that IL- $1 \alpha$ mRNA upregulation began 4-14 d after the lesion in the dorsal striatum that was just before the detectable recovery period. Moreover, a similar induction of IL- $1 \alpha$ synthesis, but one lasting for much longer periods, up to $30 \mathrm{~d}$ after the lesion, was also observed in the ventral striatum of young mice. However, in MPTP-treated middle-aged mice, the induction of IL- $1 \alpha$ 

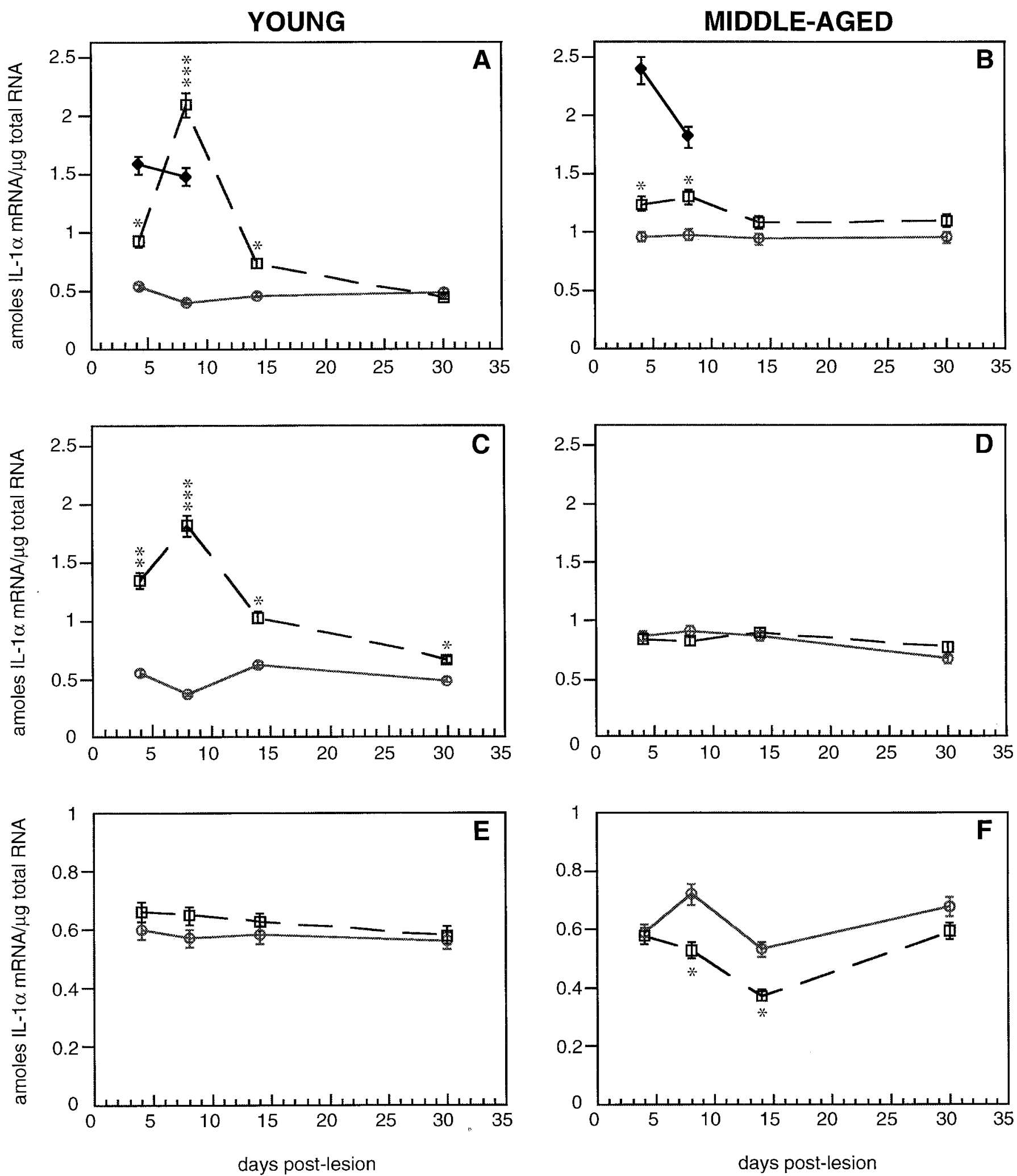

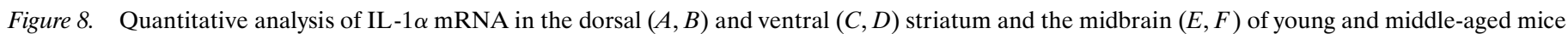

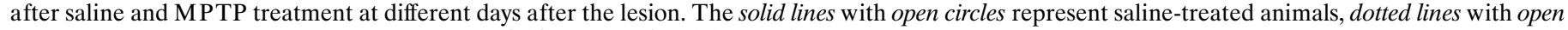

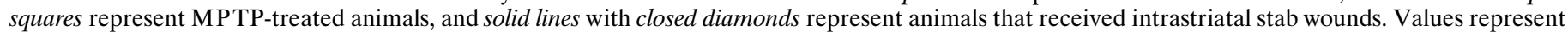

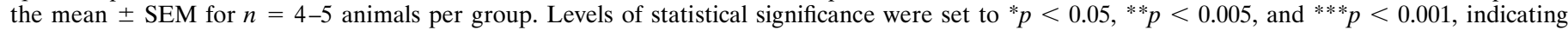
differences from an age-matched control. 

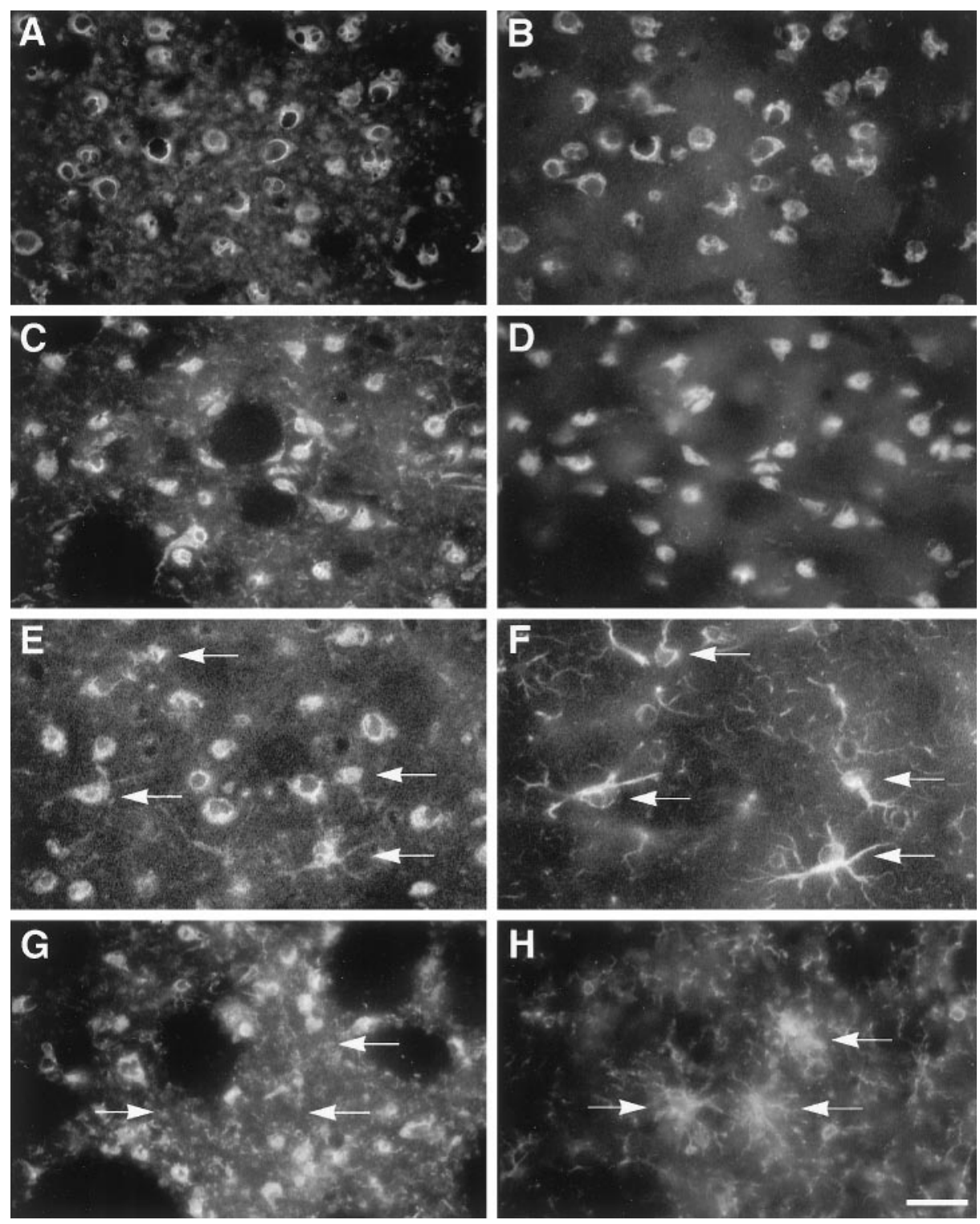

Figure 9. Cellular source of IL-1 $\alpha$ in the striatum of young mice at $8 \mathrm{~d}$ after saline and MPTP treatment. $A, B$, Colocalization of IL-1 $\alpha(A)$ and Neu N-IR neurons $(B)$ in a saline-treated animal. $C, D$, Colocalization of IL-1 $\alpha(C)$ and Neu N-IR neurons $(D)$ in an MPTP-treated animal. $E, F$, Colocalization of IL-1 $\alpha(E)$ and GFAP-IR astroglial cells $(F$; labeled with arrows in $E, F)$ in an MPTPtreated animal. $G, H, \mathrm{IL}-1 \alpha(G)$ and Mac-1-IR cells $(H$; labeled with arrows in $G, H)$ showing that IL-1 $\alpha$ expression was not distributed in Mac-1-IR microglial cells. Scale bar, $25 \mu \mathrm{m}$.
mRNA was only seen for the first $8 \mathrm{~d}$ in the dorsal striatum and not at all in the ventral striatum. The long-lasting upregulation of IL- $1 \alpha$ found both in the dorsal and ventral striatum of young mice after MPTP treatment suggests a role for IL- $1 \alpha$ in eliciting, propagating, or maintaining dopaminergic axonalsprouting processes.

Our demonstration of IL- $1 \alpha$ expression in GFAP-IR hypertrophied astrocytes and striatal neurons indicates that these cells were the predominant source of increased IL- $1 \alpha$ expression in the denervated striatum after MPTP treatment. Because we did not find IL- $1 \alpha$ expression in Mac-1-IR microglial cells, this suggests that the induction of IL-1 $\alpha$ in the denervated striatum after MPTP treatment is not occurring within activated microglia but rather in astroglia. The astroglial production of IL-1 demonstrates a functional role of reactive astrocytes in repair processes but, more importantly, extends their contribution to immunological processes in neurodegenerative disease. We found that striatal neurons also have the capacity to react to MPTP-induced injury by increased IL-1 expression. This expression in striatal neurons could be a consequence of MPTP effects to the denervated afferent pro- jections connected with the lesioned area. Neurons have been implicated to function as a source of cytokines (Breder et al., 1988; Lechan et al., 1990; Tchelingerian et al., 1993); however, the role of cytokine production in neuronal cell types associated with neurodegenerative disease has not been described. The data presented open a new perspective on neuron-astroglia interactions associated with the cytokine network during brain function and neurodegeneration.

A striking observation was that activation of IL- $1 \alpha$ in response to MPTP is region specific. We found that although a glial reaction accompanied the dopaminergic cell loss in the midbrain, activation of IL- $1 \alpha$ mRNA was not observed in the midbrain in either age group. In fact, middle-aged mice displayed a significant downregulation of IL- $1 \alpha$ mRNA in the midbrain after MPTP treatment. This finding suggests that the midbrain elicits a different inflammatory mechanism that is independent of IL- $1 \alpha$ activation.

IL-1 $\alpha$ effects on dopaminergic axonal sprouting after MPTP treatment may not be indirectly mediated via stimulating enhanced astroglial synthesis of dopaminergic neurotrophic factors as originally hypothesized. We have described here that 

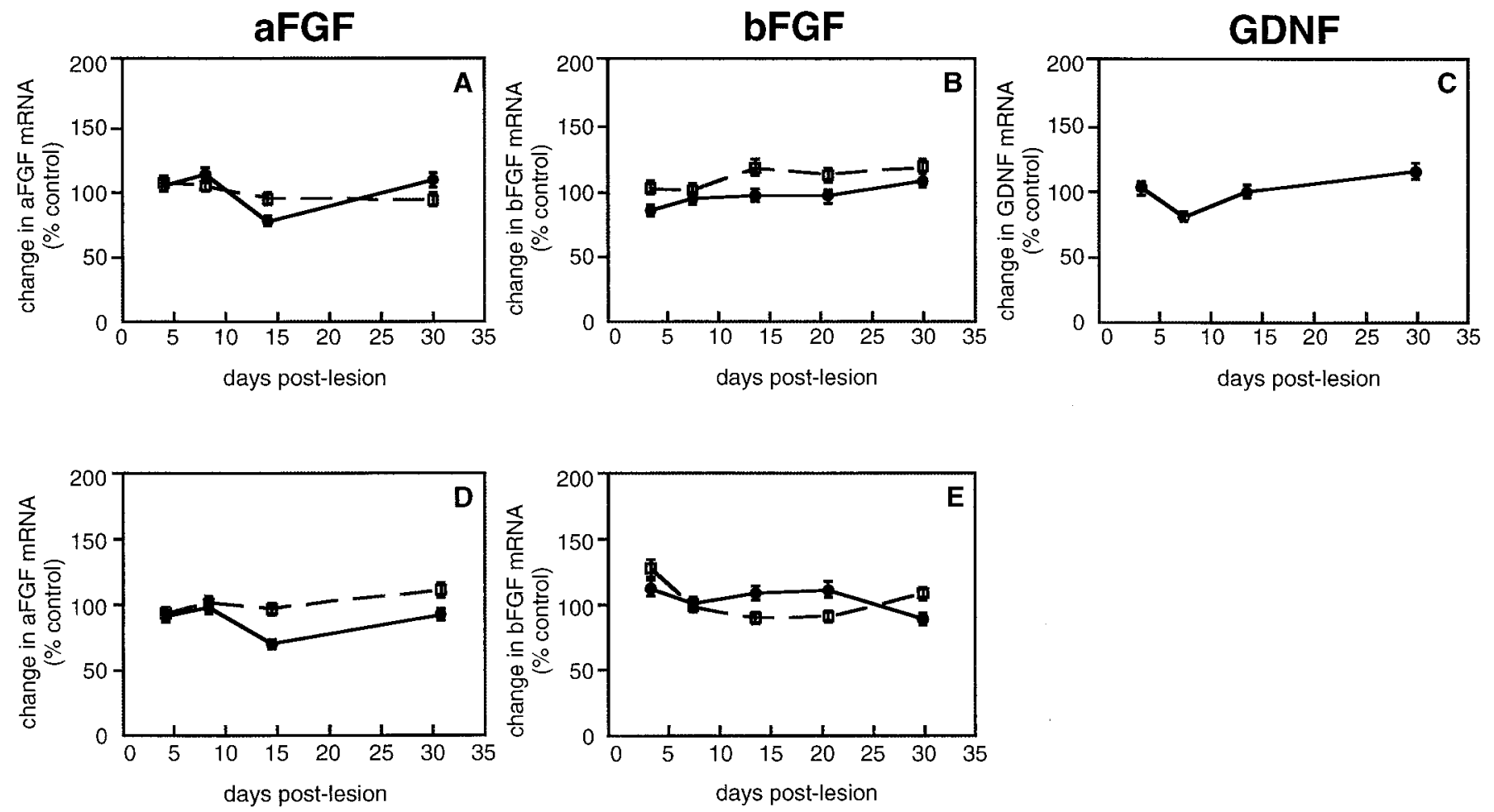

Figure 10. Quantitative analysis of dopaminergic neurotrophic factor synthesis in the striatum of young and middle-aged mice at different times after MPTP treatment. The solid lines represent young MPTP-treated mice, and the dotted lines represent middle-aged MPTP-treated mice. Values are presented as the change in mean as expressed in percent control \pm SEM for $n=4-5$ animals per group. $A, D$, Changes in aFGF mRNA in the dorsal $(A)$ and ventral $(D)$ striatum. $B, E$, Changes in bFGF mRNA in the dorsal $(B)$ and ventral $(E)$ striatum. $C$, Changes in GDNF mRNA levels in the dorsal striatum of young MPTP-treated mice.

the induction of IL- $1 \alpha$ mRNA in young mice after MPTP treatment was not accompanied by a secondary induction of astroglia-derived factors such as aFGF, bFGF, or GDNF synthesis; however, we cannot exclude the possibility that protein levels may be altered. This finding suggests that the synthesis of these dopaminergic neurotrophic factors was not critical for the lesion-induced plasticity of dopaminergic neurons. Our results are different from data reported by Leonard et al. (1993) in which both aFGF and bFGF mRNAs were found to increase in the denervated striatum at 1 week after the lesion. This difference in results could be a consequence of strain differences or of the dosage of MPTP administered (Sundström et al., 1987). The upregulation of these factors was reported in Swiss-webster mice that have been shown to be particularly resistant to MPTP toxicity (Sundström et al., 1987; Leonard et al., 1993). MPTP toxicity was shown to be restricted only to fiber damage with no degeneration of dopaminergic neurons in Swiss-webster mice, whereas the C57BL/6 strain, which we have used, was shown to display a marked loss of dopaminergic neurons in response to MPTP (Leonard et al., 1993).

In contrast to our original hypothesis that dopaminergic trophic factors could mediate IL- $1 \alpha$ lesion-induced plasticity of dopaminergic neurons, IL- $1 \alpha$ may act directly on dopaminergic cells. It has been suggested that IL-1 may act as a target-derived neurotrophic factor because autoradiography studies have shown a distribution of IL-1 receptor binding in the SN (Farrar et al., 1987; Akaneya et al., 1995). Our doublelabeling experiments revealed that IL-1 receptor expression was found within TH-IR cell bodies lying both in the SN and
VTA. We found that after MPTP treatment, IL-1 receptor expression remained within TH-IR cell bodies particularly in the VTA and in some TH-IR cell bodies scattered in the SN. This finding provides further evidence of a direct effect of IL $-1 \alpha$ on dopaminergic cells. Inhibiting the action of IL $-1 \alpha$ by blocking its receptor via the administration of IL-1 receptor antagonist could be helpful to assess whether IL- $1 \alpha$ is responsible for spontaneous dopaminergic sprouting in young mice after MPTP treatment.

\section{Aging and neurodegeneration}

The decline in IL- $1 \alpha$ activation in middle-aged mice seems to depend on the nature of the injury, considering that IL-1 $\alpha$ was found to be induced to a greater extent after intrastriatal stab wound injury. This finding suggests that MPTP propagates a differential immune reaction as the brain ages that could lead to the attenuated recovery. Hence, understanding immunological responses differing between young and aged brain is of great importance, especially regarding neural transplants for the treatment of PD. Grafting dopamine-producing tissues such as adrenal medullary chromaffin cells or fetal ventral mesencephalon into the striatum of animal models of PD and parkinsonian patients have been shown to induce a compensatory sprouting response from residual host neurons and to ameliorate some motor deficits (Bohn et al., 1987; Fiandaca et al., 1988; Lindvall, 1989; Bankiewicz et al., 1991). However, such benefits are greatly diminished in aged animals (Date et al., 1989, 1994). The mechanism of recovery has been difficult to interpret because of limited survival of implanted cells and tissues (Bankiewicz et al., 1988; Fiandaca et al., 1988). Inter- 

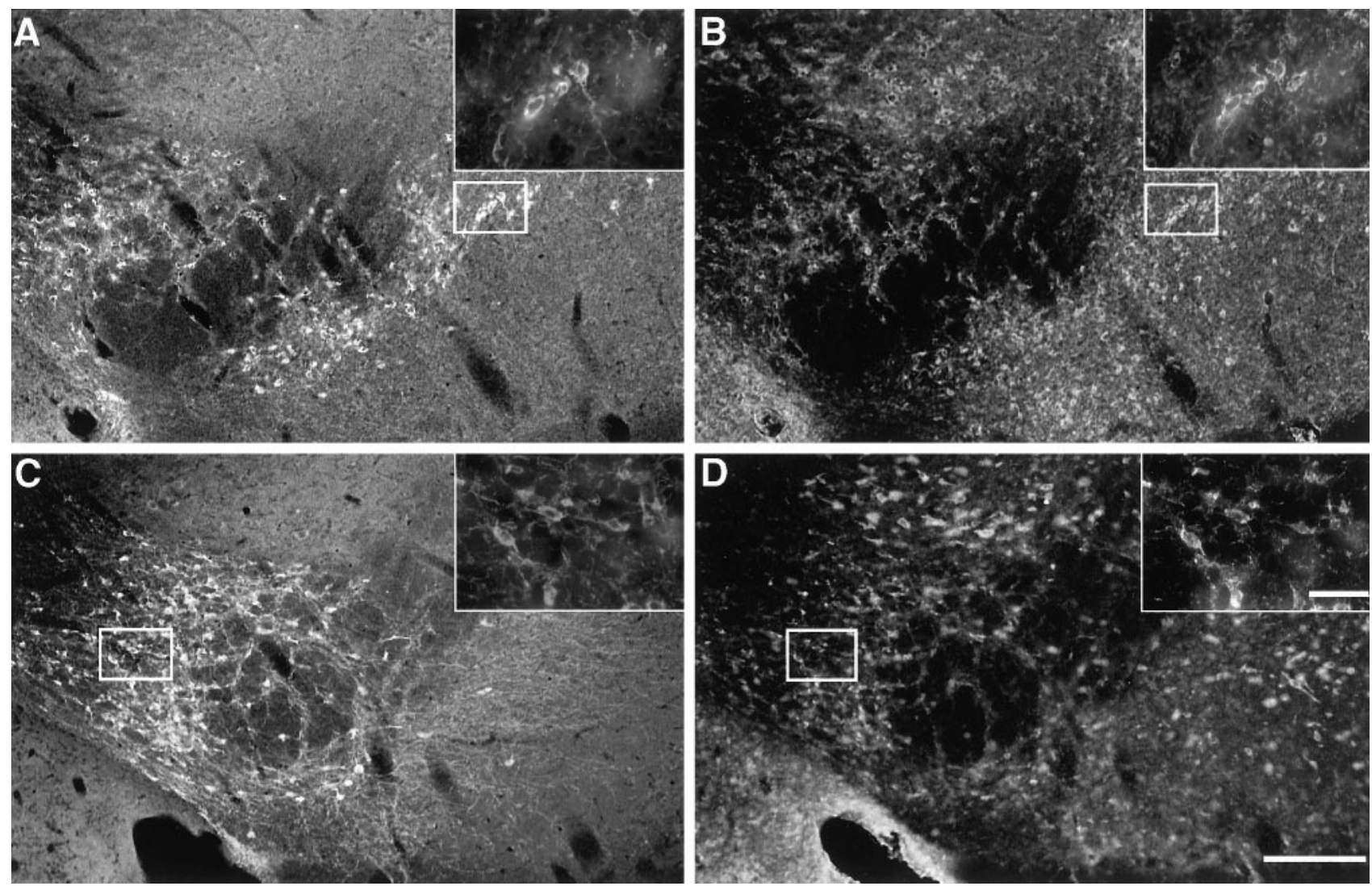

Figure 11. TH-IR cell bodies in the midbrain contain IL-1 receptor in saline- and MPTP-treated young mice. $A, B$, Colocalization of TH-IR neurons $(A)$ with IL-1 receptor expression $(B)$ distributed in the SN and VTA of a saline-treated animal. Upper right-hand panels are high-power magnification of the representative box outlined in the SN. $C, D$, Colocalization of TH-IR neurons in the VTA $(C)$ with IL-1 receptor expression $(D)$ of a MPTP-treated animal. Scale bars: $A-D, 200 \mu \mathrm{m}$; high-power magnifications, $50 \mu \mathrm{m}$.

estingly, it was shown that trauma (cavitation) alone in the striatum promotes a similar functional recovery in hemiparkinsonian monkeys, suggesting the presence of neuritepromoting factors as a result of the trauma (Plunkett et al., 1990). Inflammatory cells and reactive glia around the grafts have been implicated to mediate the transplantation-induced compensatory sprouting when intrastriatal implantation of microglia or activated leukocytes was shown to promote functional recovery (Wang et al., 1991; Ewing et al., 1992). Further investigation determined that a key mediator of inflammation in the brain, IL-1, was the potential component through which neural transplants exert their growth-promoting effects in parkinsonian animals (Wang et al., 1994). In light of these findings, here we report that although middle-aged mice showed a faster glial reaction compared with that in young mice after MPTP treatment, the ability to induce IL $-1 \alpha$ dramatically declined with age. Such age-related alterations in inflammatory reaction could explain the decrease in neurite-promoting activities and the functional recovery after transplantation of cells in parkinsonian aged animals.

In conclusion, the present experiments demonstrated that (1) induction of IL- $1 \alpha$ mRNA in the dorsal and ventral striatum is associated with compensatory dopaminergic sprouting, (2) induction of IL- $1 \alpha$ mRNA is region specific and varies with age in response to MPTP, and (3) IL- $1 \alpha$ neurotrophic actions on axonal sprouting may be directly acting on dopaminergic neurons. Investigating the regulation of IL-1 and its interactions with other factors, substrates, and extracellular matrix molecules could lead to a better understanding of factors attenuating neuronal plasticity in the aging brain and to therapeutic approaches to treating neurodegenerative disorders.

\section{REFERENCES}

Agid Y, Javoy-Agid F, Ruberg M (1987) Biochemistry of neurotransmitters in Parkinson's disease. Mov Disord 2:166-230.

Akaneya Y, Takahashi M, Hatanaka H (1995) Interleukin-1 $\beta$ enhances survival and interleukin- 6 protects against MPP + neurotoxicity in cultures of fetal rat dopaminergic neurons. Exp Neurol 136:44-52.

Araujo D, Cotman C (1992) Basic FGF in astoglial, microglial, and neuronal cultures: characterization of binding sites and modulation of release by lymphokines and trophic factors. J Neurosci 12:1668-1678.

Bankiewicz KS, Plunkett RJ, Kopin IJ, Jacobowitz DM, London WT, Oldfield EH (1988) Transient behavioral recovery in hemiparkinsonian primates after adrenal medullary allografts. Prog Brain Res 78:543-549

Bankiewicz KS, Plunkett RJ, Jacobowitz DM, Kopin IJ, Oldfield EH (1991) Sprouting-induced recovery from MPTP-induced parkinsonism in primates after fetal non-dopaminergic brain implants: histochemical and behavioral studies. J Neurosurg 74:97-101.

Beller D, Springer T, Schreiber R (1982) Anti-Mac-1 inhibits the mouse and human type three complement receptor. J Exp Med 156:1000-1009.

Björklund A, Lindvall O (1984) Dopamine-containing system in the CNS. In: Handbook of chemical neuroanatomy, Vol 2 (Björklund A, Lindvall O, eds), pp 55-111. Amsterdam: Elsevier.

Blanchard V, Anglade P, Dziewczapolski G, Savasta M, Raisman-Vozari $\mathrm{R}$ (1996) Dopaminergic sprouting in the rat striatum after partial lesion of the substantia nigra. Brain Res 709:319-325.

Bohn MC, Cupit L, Marciano F, Gash DM (1987) Adrenal medulla 
grafts enhance recovery of striatal dopaminergic fibers. Science 237:913-916.

Breder S, Dinarello C, Laper C (1988) Interleukin-1 immunoreactive innervation of the human hypothalamus. Science 240:321-324.

Czlonkowska A, Kohutnicka M, Kurkowska-Jastrzebska I, Czlonkowski A (1996) Microglial reaction in MPTP (1-methyl-4-phenyl-1,2,3,6tetrahydropyridine) induced Parkinson's disease in mice model. Neurodegeneration 5:137-143.

Date I, Felten SY, Felten DL (1989) Exogenous GM1 gangliosides induce partial recovery of the nigrostriatal dopaminergic system in MPTP-treated young mice but not in aging mice. Neurosci Lett 106:282-286.

Date I, Felten D, Felten S (1990a) Long-term effect of MPTP in the mouse brain in relation to aging: neurochemical and immunocytochemical analysis. Brain Res 519:266-276.

Date I, Notter M, Felten S, Felten D (1990b) MPTP-treated young mice but not aging mice show partial recovery of the nigrostriatal dopaminergic system by stereotaxic injection of acidic fibroblast growth factor (aFGF). Brain Res 526:156-160.

Date I, Yoshimoto Y, Takashi I, Yasuyuki M, Futura T, Asari S, Ohmoto T (1994) Effect of host age upon the degree of nigrostriatal dopaminergic system recovery following cografts of adrenal medulla and pretransected peripheral nerve. Brain Res 637:50-56.

Eddleston M, Mücke L (1993) Molecular profile of reactive astrocytesimplications for their role in neurological disease. Neuroscience 54:15-36.

Ewing SE, Weber RJ, Zauner A, Plunkett RJ (1992) Recovery in hemiparkinsonian rats following intrastriatal implantation of activated leukocytes. Brain Res 576:42-48.

Farrar W, Killian P, Ruff M, Hill J, Pert C (1987) Visualization and characterization of interleukin-1 receptors in brain. $\mathrm{J}$ Immunol 139:459-463.

Fiandaca MS, Kordower JH, Hansen JT, Jiao SS, Gash DM (1988) Adrenal medullary autografts into the basal ganglia of cebus monkeys: injury induced regeneration. Exp Neurol 102:76-91.

Fontana A, Kristensen F, Dubs R, Gemsa D, Weber E (1982) Production of prostaglandin $\mathrm{E}$ and interleukin-1 like factor by cultured astrocytes and C glioma cells. J Immunol 129:2413-2419.

Francis JW, Visger JV, Markelonis GJ, Oh TH (1995) Neuroglial responses to the dopaminergic neurotoxicant 1-methyl-4-phenyl1,2,3,6-tetrahydropyridine in mouse striatum. Neurotoxicol Teratol $17: 7-12$.

German D, Manaye D, Smith W, Woodward D, Saper C (1989) Midbrain dopaminergic cell loss in Parkinson's disease: computer visualization. Ann Neurol 26:507-514.

Gilad G, Reis D (1979) Collateral sprouting in central mesolimbic dopamine neurons: biochemical and immunocytochemical evidence of changes in the activity and distribution of tyrosine hydroxylase in terminal field and in cell bodies of A10 neurons. Brain Res 160:17-36.

Giulian D (1987) Ameboid microglia as effectors of inflammation in the central nervous system. J Neurosci Res 18:155-171.

Giulian D (1990) Microglia, cytokines, and cytotoxins: modulators of cellular responses after injury to the central nervous system. J Immunol Immunopharmacol 10:15-21.

Giulian D, Lachman L (1985) Interleukin-1 stimulation of astroglial proliferation after brain injury. Science 228:487-499.

Giulian D, Baker T, Shin L-C, Lachman L (1986) Interleukin-1 of the central nervous system is produced by ameboid microglia. J Exp Med 164:594-604.

Giulian D, Woodward J, Young D, Krebs J, Lachman L (1988) Interleukin-1 injected into mammalian brain stimulates astrogliosis and neovascularization. J Neurosci 8:2485-2490.

Giulian D, Chen J, Ingeman J, George J, Noponen M (1989) The role of mononuclear phagocytes in wound healing after traumatic injury to adult mammalian brain. J Neurosci 9:4416-4429.

Goss J, Finch C, Morgan D (1991) Age-related changes in glial fibrillary acidic protein mRNA in the mouse brain. Neurobiol Aging 12:165-170.

Hansen J, Sakai K, Greenamyre J, Moran S (1995) Sprouting of dopaminergic fibers from spared mesencephalic dopamine neurons in the unilateral partial lesioned rat. Brain Res 670:197-204.

Hetier E, Ayala J, Denefle P, Bousseau A, Rouget P, Malat M, Prochiantz A (1988) Brain macrophages synthesize interleukin-1 and interleukin-1 mRNAs in vitro. J Neurosci Res 21:391-397.

Hirsch E, Graybiel A, Agid Y (1988) Melanized dopaminergic neurons are differentially susceptible to degeneration in Parkinson's disease. Nature 334:345-348.

Ho A, Blum M (1997) Regulation of astroglia-derived dopaminergic neurotrophic factors by interleukin- $1 \beta$ in the striatum of young and middle-aged mice. Exp Neurol 148:348-359.

Hoff S, Scheff S, Cotman C (1982a) Lesion-induced synaptogenesis in the dentate gyrus of aged rats: I. Loss and reacquisition of normal synaptic density. J Comp Neurol 205:246-252.

Hoff S, Scheff S, Cotman C (1982b) Lesion-induced synaptogenesis in the dentate gyrus of aged rats: II. Demonstration of an impaired clearing response. J Comp Neurol 205:253-259.

Hornykiewicz O (1993) Parkinson's disease and the adaptive capacity of the nigrostriatal dopamine system: possible neurochemical mechanisms. In: Advances in neurology, Vol 60 (Narabayashi H, Nagatsu T, Yanagiswa N, Mizuno Y, eds), pp 140-147. New York: Raven.

Jackson-Lewis V, Jakowec M, Burke RE, Przedborski S (1995) Time course and morphology of dopaminergic neuronal death caused by the neurotoxin 1-methyl-4-phenyl-1,2,3,6-tetrahydropyridine. Neurodegeneration 4:257-269.

Kitt CA, Cork LC, Eidelberg F, Joh TH, Price DL (1986) Injury of nigral neurons exposed to 1-methyl-4-phenyl-1,2,3,6-tetrahydropyridine: a tyrosine hydroxylase immunocytochemical study in monkey. Neuroscience 17:1089-1103.

Langston J (1985) MPTP and Parkinson's disease. Trends Neurosci $8: 79-83$.

Lechan R, Toni R, Clark B, Cannon J, Shaw A, Dinarello C, Reichlin S (1990) Immunoreactive interleukin-1 $\beta$ localization in the rat forebrain. Brain Res 514:135-140.

Leonard S, Luthman D, Logel J, Luthman J, Antle C, Freedman R, Hoffer B (1993) Acidic and basic fibroblast growth factor mRNAs are increased in striatum following MPTP-induced dopamine neurofiber lesion: assay by quantitative PCR. Mol Brain Res 18:275-284.

Lindvall O (1989) Transplantation into the human brain: present status and future possibilities. J Neurol Neurosurg Psychiatry [Suppl] 52:39-43.

March C, Mosley B, Larsen A, Cerretti D, Braedt G, Price V, Gillis S, Henney C, Kronheim S, Grabstein K, Conlon P, Hopp T, Cosman D (1985) Cloning, sequencing and expression of two distinct human interleukin-1 complementary DNAs. Nature 315:641-647.

Moore S, Thanos S (1996) The concept of microglia in relation to central nervous system disease and regeneration. Prog Neurobiol 48:441-460.

Otto D, Unsicker K (1990) Basic FGF reverses chemical and morphological deficits in the nigrostriatal system of MPTP-treated mice. J Neurosci 10:1912-1921.

Plunkett RJ, Bankiewicz KS, Cummins AC, Miletich RS, Schwartz JP, Oldfield EH (1990) Long-term evaluation of hemiparkinsonian monkeys after adrenal autografting or cavitation alone. J Neurosurg 73:918-926.

Ricaurte G, Langston J, Delanney L, Irwin I, Peroutka S, Forno L (1986) Fate of nigrostriatal neurons in young mature mice given 1-methyl-4phenyl-1,2,3,6-tetrahydropyridine: a neurochemical and morphological reassessment. Brain Res 376:117-124.

Ricaurte G, DeLanney L, Irwin I, Langston J (1987a) Older dopaminergic neurons do not recover from the effects of MPTP. Neuropharmacology 26:97-99.

Ricaurte G, Irwin I, Forno L, DeLanney L, Langston E, Langston J (1987b) Aging and 1-methyl-4-phenyl-1,2,3,6-tetrahydropyridineinduced degeneration of dopaminergic neurons in the substantia nigra. Brain Res 403:43-51.

Rivera S, Gold S, Gall C (1994) Interleukin-1 $\beta$ increases basic fibroblast growth factor mRNA expression in adult rat brain and organotypic hippocampal cultures. Mol Brain Res 27:12-26.

Roffler-Tarlov S, Pugatch D, Graybiel AM (1990) Patterns of cell and fiber vulnerability in the mesostriatal system of the mutant mouse weaver. II. High affinity uptake sites for dopamine. J Neurosci 10:734-740

Singer T, Ramsay R (1990) Mechanism of the neurotoxicity of MPTP. FEBS Lett 274:1-8.

Spranger M, Lindholm D, Bandtlow C, Heumann R, Gnahn H, NaherNoe M, Thoenen H (1990) Regulation of nerve growth factor (NGF) synthesis in the rat central nervous system: comparison between the effects of interleukin-1 and various growth factors in astrocyte cultures and in vivo. Eur J Neurosci 2:69-76.

Springer T, Galfre G, Secher D, Milstein C (1979) Mac-1: a macrophage 
differentiation antigen identified by monoclonal antibody. Eur J Immunol 9:301-306.

Sundström E, Strömberg I, Tsutumi T, Olson L, Jonsson G (1987) Studies of the effects of 1-methyl-4-phenyl-1,2,3,6-tetrahydropyridine (MPTP) on central catecholamine neurons in C57BL/6 mice. Comparison with three other strains of mice. Brain Res 405:26-38.

Sundström E, Luthman J, Goldstein M, Jonsson G (1988) Time course of MPTP-induced degeneration of the nigrostriatal dopamine system in C57BL/6 mice. Brain Res Bull 21:257-263.

Tchelingerian J, Quinonero J, Booss J, Jacque C (1993) Localization of TNF $\alpha$ and IL- $1 \alpha$ immunoreactivities in striatal neurons after surgical injury to the hippocampus. Neuron 10:213-224.
Tomac A, Lindqvist E, Lin L, Ögren S, Young D, Hoffer B, Olson L (1995) Protection and repair of the nigrostriatal dopaminergic system by GDNF in vivo. Nature 373:335-339.

Wang J, Bankiewicz KS, Plunkett RJ, Sheng J, Jacobowitz DM (1991) Transplantation of microglia reduces experimental parkinsonism in rats. In: Intracerebral transplantation in movement disorders (Lindvall O, Björklund A, Widner H, eds), pp 313-323. Amsterdam: Elsevier.

Wang J, Bankiewicz KS, Plunkett RJ, Oldfield EH (1994) Intrastriatal implantation of interleukin-1: reduction of parkinsonism in rats by enhancing neuronal sprouting from residual dopaminergic neurons in the ventral tegmental area of the midbrain. J Neurosurg 80: $484-490$. 